\title{
Diagnosing Contact Processes from their Outcomes: The Importance of Life Stages
}

\author{
Malcolm Ross \\ College of Asia and the Pacific, The Australian National University \\ malcolm.ross@anu.edu.au
}

\begin{abstract}
This paper addresses the questions, Do bilingually induced and shift-induced change have different outcomes? If they do, can these differences assist us in reconstructing the prehistoric past, specifically the linguistic prehistory of the (smallscale neolithic) societies of Melanesia.

A key to better interpreting differences in the outputs of contact-induced change is to understand how such change in smallscale societies actually occurs. I argue that it is important to know the life-stage loci of change. I suggest that language shift has two life-stage loci, one in early childhood, where evidence of shift, if any, is restricted to specialist lexicon, and one in adulthood. Adult language shift appears to have been rare in Melanesia. I also suggest that bilingually induced change, which entails the syntactic restructuring of one's heritage language on the model of a second language, takes place among preadolescent children-a claim which is supported by various kinds of evidence.

This understanding helps us in turn to interpret the outcomes of contact-induced change and to infer prehistoric events, since adult second-language learning typically leads to simplification, whilst childhood language learning may lead to an increase in complexity.
\end{abstract}

\section{Keywords}

language shift; bilingualism; metatypy; prehistory; Melanesia; life stages

\section{Introduction}

\subsection{Prospectus}

This paper reports a search for answers to the question, Do bilingually induced and shift-induced change have different outcomes? ${ }^{1}$

1 This paper is based on a keynote talk given at the Rethinking Contact Induced Change conference which took place from 9-11 June 2011 in Leiden to celebrate the transfer of the Journal of Language Contact to Brill. My thanks go to the instigator of the conference, Robert Nicolai, and its sponsor, Brill, for inviting me to attend. A similar talk followed at the Max Planck Institute for Evolutionary Anthropology in Leipzig. I would like to thank Bernard Comrie, Bethwyn 
By 'bilingually induced change' I mean change which bilingual speakers introduce into one of their languages on the model of their other language, the process that I have elsewhere labelled calquing and metatypy (Ross 2007). Here I label it more simply 'bilingual copying'.

By 'shift-induced change' I mean changes introduced by shifting speakers into (the version of) the language to which they are shifting.

If there are differences in the outputs of bilingually induced change and shift-induced change, this allows us to reconstruct a language's contact history more accurately. That history may include a sequence of contact events that is difficult to unravel, but, as will become evident below, I think it is often still possible to detect contact-induced change events in a language's history, and not to attempt this is to be too easily defeated by the complexities of history. Sometimes reconstructing a prehistoric contact event means positing the existence of a language for which we have only contact evidence, and this issue is discussed briefly in $\$ 1.4$.

This study is motivated by my interest in prehistoric language contact in smallscale neolithic speech communities in Melanesia. Section 1.2 provides some basic information about the languages of Melanesia, together with a striking example. Section 1.3 explains why the discussion of sociolinguistic processes is restricted here to bilingually induced and shift-induced change: because other contact situations are unlikely to have occurred in neolithic societies.

In $\$ 2$ I ask the question, How can we reliably know what the typical outcomes of bilingually induced and shift-induced change actually are? The first step is to look for cases in the literature where we know the linguistic outcome of a contact event and also have independent attestation of the situation in which it occurs $(\$ 2.1)$. There are remarkably few such cases. A more fruitful route to an answer is to ask how contact-induced change takes place. The literatures of variationist sociolinguistics and bilingual acquisition point to the importance of the life stage at which contact-induced change occurs $(\$ 2.2)$, indicating that changes that occur in young people's speech $(\$ 2.2 .1)$ are likely to differ from changes in adults' speech (\$2.2.2). I argue in $\$ 3.1$ that various

Evans, Martin Haspelmath, Felicity Meakins, Sebastian Nordhoff, Carmel O'Shannessy, Brigitte Pakendorf, Andrew Pawley and Eugenie Stapert for comments on earlier drafts and at the presentations of this paper.

${ }^{2}$ I prefer to avoid the term 'borrowing', partly because I share Johanson's (2002) objection that copies are rarely total replications, but also because I prefer to use 'borrowing' in van Coetsem’s sense, which I return to briefly in $\$ 3.1$. 
pieces of evidence from these linguistic subdisciplines point to preadolescence and adolescence as the locus of bilingually induced change. Language shift (\$3.2), on the other hand, needs to be treated as two separate phenomena, according to whether it takes place over generations (the usual situation, where children are the locus of change) or abruptly because of a communal crisis that precipitates shift by adults. My claim is that each life-stage locus of contact-induced change leads to certain kinds of outcome, and that this in turn provides us with diagnostics that we can sometimes use in the historical reconstruction of contact $(\$ 4)$. It is widely agreed that children readily acquire linguistic complexity whereas adults generally don't (Kerswill 1996; Dahl 2004:294; Trudgill 2001, 2009; Wray \& Grace 2007; Lupyan \& Dale 2010; Thomason 2010), and so increase or decrease in complexity in contactinduced change may help us to diagnose the circumstances of change.

\subsection{Prehistoric contact in Melanesia: background}

The languages of Melanesia (New Guinea, Solomon Islands, Vanuatu and New Caledonia; Figure 1) fall into two sets, Austronesian and Papuan.

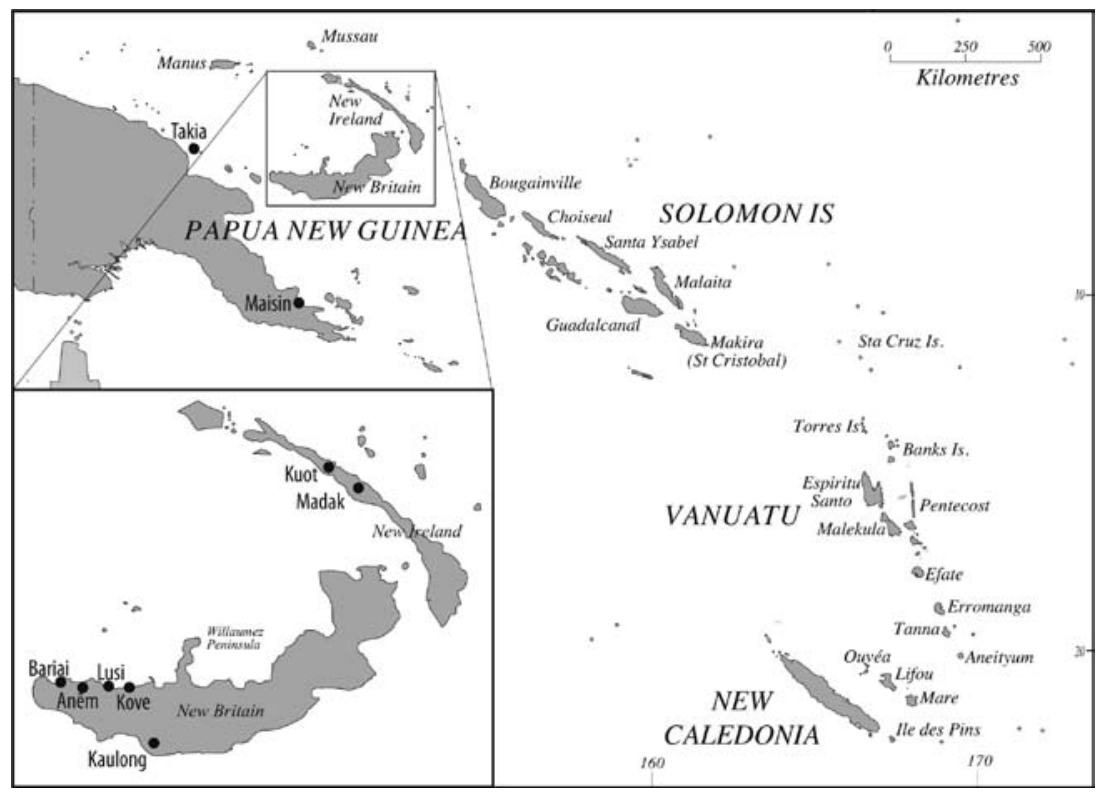

Figure 1. Locations of languages in Melanesia mentioned in the text. 


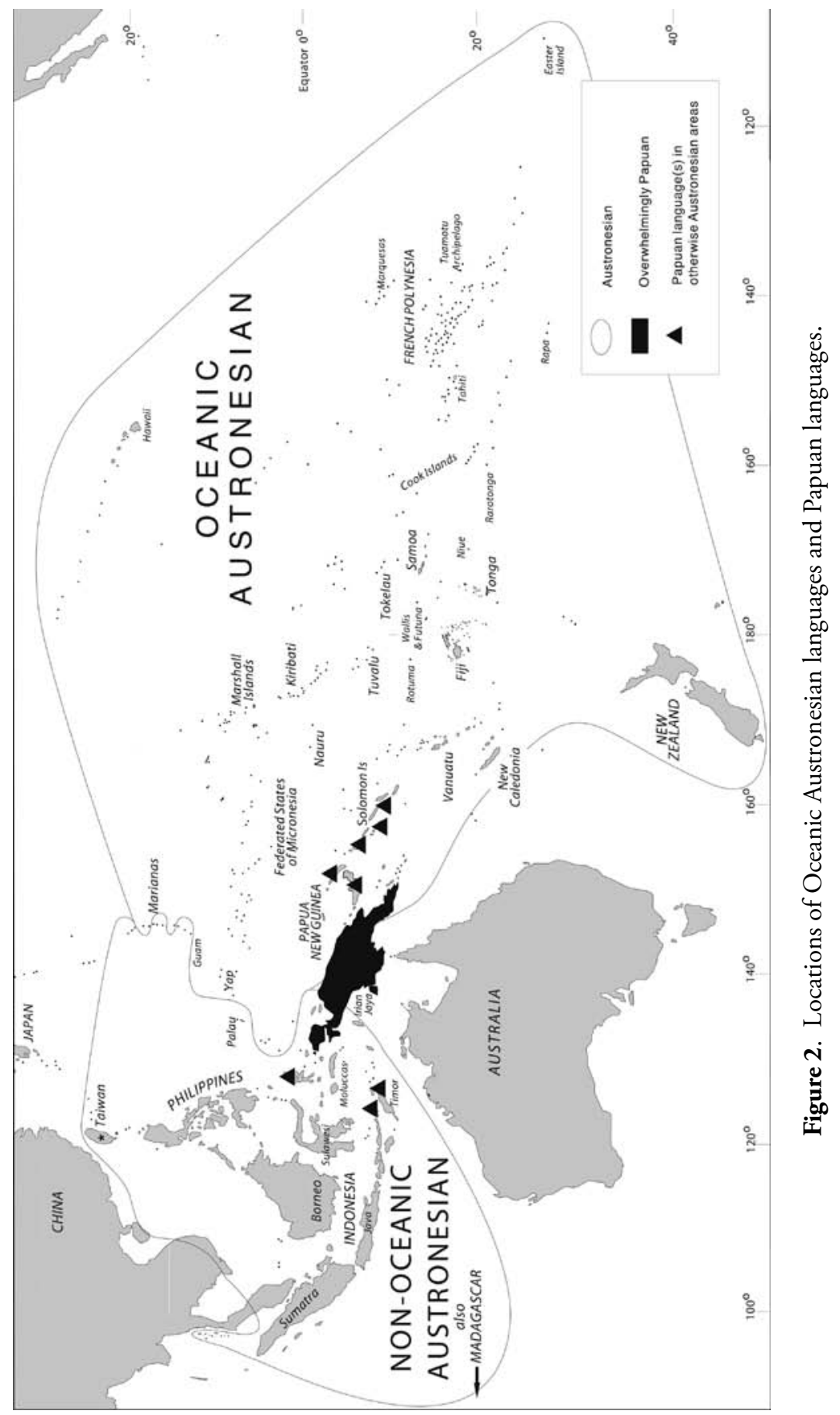


The Austronesian languages occupy the huge area shown on the map in Figure 2. Proto Austronesian was spoken in Taiwan. By 2200 BC Austronesian speakers had settled in the Philippines (Hung 2005; Bellwood \& Dizon 2008), and within a thousand years had occupied much of the area shown on the map as far east as Fiji, Samoa and Tonga. In the course of their spread they encountered speakers of pre-Austronesian languages whose ancestors had apparently arrived in the region from SE Asia about 40,000 years ago and had settled as far as the southeastern end of Greater Bougainville, the Pleistocene island which included Bougainville, Choiseul, Santa Isabel and the Florida group (of small islands between Santa Isabel and Guadalcanal). Descendants of these pre-Austronesian languages survive only in Australia and the New Guinea region. The pre-Austronesian languages of Timor, Halmahera, New Guinea and the Solomon Islands are known as Papuan languages, but they do not form a known genealogical unity. Instead, 'Papuan' languages are simply languages of this region that are not Austronesian and not Australian. ${ }^{3}$

If 'prehistoric' means 'before written history', and this in turn means 'before contact with largescale societies', then Melanesian prehistory stretches forward into the mid-19th century and in some places to as recently as the 1930s, when German and Australian explorers reached the highlands of inland Papua New Guinea.

When these prehistoric contacts took place, none of these communities had moved beyond neolithic agriculture and some Papuan speaking societies were perhaps still mesolithic, living from hunting and gathering and practising rudimentary arboriculture. The neolithic societies were not very different from some of today's rural societies in Papua New Guinea. They practised shifting smallscale agriculture in addition to hunting and gathering, and kept pigs and chickens for feast food, but didn't employ animals as sources of labour or for their secondary products. ${ }^{4}$

I argue below that almost all easily detected cases of contact-induced change in Melanesia are cases of bilingually induced change. Shift must surely have occurred, but its outcomes are invisible if we do not have sizeable quantities of lexical data from both the languages involved in the shift, or from the language which has undergone shift-induced change together with parallel data from a language closely related to it that has not undergone such change.

\footnotetext{
3 There are more than 20 distinct Papuan families between which no one has yet established a genealogical relationship (Pawley 2006; Ross 2005).

${ }^{4}$ Linguistic evidence of Proto Oceanic speakers' lifestyle is provided by the reconstructions and accomanying discussion in Ross, Pawley \& Osmond (1998, 2008, 2011).
} 
François (2011) brilliantly illustrates bilingually induced change in Melanesian communities. François takes the 17 Oceanic Austronesian languages of the Banks and Torres Islands of northern Vanuatu (see Figure 1) and shows that they are very similar in their grammatical structures, in their phaseology and idioms, and in their lexical polysemies, so that it is usually possible to translate word-for-word from one to the other, and often morpheme-formorpheme. Example (1) contains only six languages: François lists the sentence in all seventeen.

At first blush this structural isomorphism is not surprising, since, genealogically speaking, these languages are closely related to each other. However, their convergence in lexical-conceptual and grammatical structure (calquing) is counterbalanced by considerable divergence in their phonologies and in the forms of their morphemes. These two tendencies appear to contradict each other. If the languages are closely related and retain similarities in structure, then why are their forms so divergent? Conversely, if they have diverged so greatly in their forms, why have they not diverged in their structures? François' answer is that the convergence in structure is not merely due to shared inheritance but to significant multilingualism leading to bilingual copying. The divergence in form, on the other hand, reflects an ideological bias towards a local cultural autonomy of which differences in form are an emblem. The result, in François' words is 'one grammar, seventeen lexicons'.

The linguistic situation that François describes can be replicated in varying degrees over and over in Melanesia, among Oceanic Austronesian languages, among the Papuan languages of New Guinea (e.g. Foley 1986:25), and between Oceanic and Papuan languages (Thurston 1987, Ross 1996). Rather similar situations have been described by Enfield (2003) in mainland SE Asia and by Aikhenvald $(2002,2007)$ in the Vaupés region of Amazonia.

\begin{tabular}{|c|c|c|c|c|c|c|c|c|c|}
\hline Hiw & sisə & tati & jөjmər ${ }^{g}$ Len & wuำวY & $\mathrm{k}^{\mathrm{w}} \mathrm{e}$ & $\mathrm{i}$ & nə & məџa & ta \\
\hline Lo-Toga & nihə & tat & lolməren & $\operatorname{tr} \beta \varepsilon$ & $\mathrm{k}^{\mathrm{w}} \mathcal{\varepsilon}$ & $\mathrm{e}$ & nə & Зәуәßауә & mətə \\
\hline Vera'a & ${ }^{\mathrm{n}} \mathrm{dir}$ & I? & lamai & $\varepsilon n t \varepsilon \gamma$ & ?In & & In & tIktIk & $m u^{\mathrm{n}} \mathrm{dI}$ \\
\hline Vurës & $\mathrm{nIr}$ & yItI- & yilal & warey & $\mathrm{t} \varepsilon \mathrm{n}$ & & $\jmath$ & $\widehat{\mathrm{kp}}^{\mathrm{w}} \mathrm{akp}^{\mathrm{w}}$ & namøyynin \\
\hline Lakon & YI: & atI & roy & $\mathrm{k} \varepsilon \mathrm{r} \varepsilon$ & aßuh.male & & & $\varepsilon \ln a$ & -nyitf \\
\hline Mwerlap & $\mathrm{k} \varepsilon \mathrm{r}$ & ti & ßalyear & mInmIn & $\operatorname{tIk}^{\mathrm{w}} \mathrm{It} \widetilde{\varepsilon \mathrm{a}}$ & & no- & linI & $-\widehat{y \varepsilon a n}$ \\
\hline & $3 \mathrm{PL}$ & NOT.Y & ${ }_{1}$ know & properly & NOT.YET $_{2}$ & [OBL $]$ & ART & speech & $\begin{array}{l}\text { POSS : IINCL } \\
\text {.PL }\end{array}$ \\
\hline
\end{tabular}

'They don't know our language very well yet.' 


\subsection{Contact processes in smallscale neolithic communities}

The two-way division between bilingually induced and shift-induced change that is made in this paper may seem too simple. But other contact-induced change processes-koineisation, language intertwining, pidginisation and creolisation-can largely be excluded from language contact in smallscale societies, as they each involve the language of a larger speech community. Trudgill (2000) argues that widespread adult-only language contact is a postneolithic phenomenon associated mainly with the development of large fluid communities in the last 2000 years. Thus koineisation requires the integration of smaller speech communities into a larger one (Trudgill 1989:230). Language intertwining typically involves two languages, one the language of a larger social entity: Russian in Copper Island Aleut, Spanish in Media Lengua, or Australian Aboriginal Kriol in the cases described in $\$ 2.2 .1 .^{5}$ Pidginisation and creolisation begin with a sociolinguistic catastrophe in which two or more groups of speakers attempt to communicate using a poorly learned version of a lingua franca, and the resulting language becomes the native language of their children. These processes all involve larger-scale speech communities, of which there were few in the Neolithic. ${ }^{6}$

\subsection{Reconstructio ex silentio}

The title of this section is an allusion to a section in Lass (1997:209-214) with the title 'Etymologia ex silentio: contact with lost languages'. Here Lass discusses lexical items in European languages which cannot be reconstructed back to Proto Indo-European and which, according to a plausible inference, were borrowed into a reconstructed interstage from a source for which we no longer have direct evidence. He cites with admiration the work of Vennemann, who has argued that the identities of pre-Indo-European languages in Europe are partially knowable. Vennemann considers that much of mainland Europe was occupied by languages related to Basque, drawing his evidence from Hans Krahe's discovery of a fairly uniform system of hydronyms, which include terms with apparent cognates in Basque (Vennemann 1994, 2003a, 2003b,

\footnotetext{
5 Language intertwining is (often, at least) conscious and deliberate and presupposes bilingual competence. It entails an act of identity, with the community speaking the 'intertwined' language perceiving itself as participating in both the smaller and the larger community networks (Bakker \& Mous 1994).

6 There are exceptions in the later Neolithic. Thus political control of East Uvea by the Tongan kingdom from about 1400 to about 1600 AD had far-reaching linguistic consequences for East Uvean (Andrew Pawley, pers. comm.).
} 
2003c), and also points to Gensler (1993), who shows a typological correspondence between Semitic and Island Celtic. The hypothesis that Celtic reflects a Semitic substrate has, however, evoked heated debate (Baldi and Page 2006, Eska 1994, Hewitt 2007, Isaac 2007).

One area of Indo-European contact in Europe which Lass mentions and for which more familiar kinds of evidence have been offered is Germanic. Polomé (1986, 1990) suggests that much of the Germanic lexicon has no IndoEuropean cognates, and that a range of morphological innovations are due to contact (Polomé 1997). Nichols (1998:253) suggests that the basic V2 structure of Germanic clauses is also contact-induced, whilst Vennemann (2003b) attributes much of the variety of Indo-European syntax to contact.

The heat generated by these proposals suggests that some scholars find even strong circumstantial evidence of contact unacceptable, apparently because of a sense that internal sources of change should be exhausted before contact is considered. They are unwilling to accept toponymic, lexical or morphosyntactic evidence of contact unless data from the original contact languages is available for comparison. But, as Lass insists, the idea that internal sources of change should always be preferred over contact has no evidentiary basis. The insistence that evidence from contact sources should be available is understandable, but flies in the face of the fact that contact sometimes eliminates its own sources, as Reid $(\$ 3.2)$ has proposed for Philippine Negrito languages and I propose for Kaulong in $\$ 4$.

\section{The search for diagnostics: looking into the black box}

Do bilingually induced and shift-induced change have different outcomes? And if they do, can we use these outcomes to reconstruct prehistoric contact events?

Ross (2003a) attempted to use outcomes to diagnose the kind of contact (or denial of contact) that had occurred in the history of a language's speakers by relating social network structure to likely linguistic outcomes. Much of what I wrote then I stand by, but one weakness was the assumption that it was easy to distinguish the outcomes of bilingually induced change from those of shift-induced change. I no longer think it is so easy, but I am still probably more optimistic about our ability to make diagnoses than some of my colleagues are.

This brings me to a major issue. The usual approach of most contact linguists, myself included, has been to try to relate each contact situation type to certain outcomes, without considering in much detail the processes whereby 
these outcomes result from the relevant situation, i.e. from bilingually induced change or from language shift. The result has been some disagreement about what outcomes are triggered by what kinds of contact. It seems to me that progress can be made in this regard if we attempt to model what actually happens in language change situations rather than treating them as something of a black box.

To this end I have searched the literatures of three linguistic subfields in the hope of making better inferences about language contact processes in smallscale speech communities.

The first was the literature of language contact itself. In order to establish an empirical base for contact studies, we need case studies of contact where outcomes and the sociolinguistic conditions that gave rise to them are attested independently (\$2.1). There are fewer of these than one might think.

The second of the three literatures was that of variationist sociolinguistics, which focuses on the details of change and their social and life-stage placement, and should therefore provide insights into how and when contactinduced change occurs. Variationist sociolinguistics arose out of William Labov's work in the 1960s. Much of Labov's and his coworkers' studies of English dialects in the USA (Labov 1966, 1970, 1972a, 1972b; Payne 1976, 1980 ) and Kerswill's and his collaborators' work in the UK concerns dialect contact and the analysis of what does and does not happen to speakers at various ages (Kerswill \& Williams 1992; Kerswill 1994a, 1994b, 1996). Work of this kind is mostly restricted to largescale societies, but a few studies of smallscale speech communities are emerging (Stanford \& Preston 2009), and these again point to the importance of young people in language change and the rather constrained role of adults $(\$ 2.2)$.

The third literature was that of bilingual acquisition. Children must play some role in contact-induced change, and the questions here are, Which children? What role?

The literature on language acquisition by bilingual children proved disappointing until I realised that I was looking in the wrong place. The bulk of the language acquisition literature deals with children up to the age of 3 or 4 , but

Babies do not form influential social groups. Changes begin within social groups, when group members unconsciously imitate those around them. Differences in the speech forms of parents and children probably begin at a time when the two generations identify with different social sets. (Aitchison 1981:180)

The literature on the acquisition of two languages in infancy is interesting for what it does not tell us. We might expect that features associated with bilingually induced change would emerge early in bilingual learning, but they 
don't. Much research on infant bilingualism is conducted within the Minimalist framework, and Serratrice, Sorace and Paoli (2004) divide the acquisition of grammar into two phases: before and after the acquisition of CPs. ${ }^{7}$ In the first, or infant, phase, up to 3 years or so, children learning two languages tend to make the same 'errors' as monolingual children learning the same languages but attain their targets more slowly than monolinguals. The kinds of crosslinguistic interference that are claimed, e.g. by Hulk \& Müller (2000) and Müller \& Hulk (2001), are so subtle that Serratrice et al. question whether the claims are valid. Interference at this stage in any case bears little resemblance to the effects of contact.

After the acquisition of CPs, the situation changes. Matthews \& Yip (2009), studying Cantonese-English bilingualism in their own family, write that the parallels between the language development of their bilingual children and contact-induced grammatical change are so strong as to suggest that learning by bilingual children may be a significant source of contact-induced grammatical change. ${ }^{8}$ Their claims are born out by the emergence of new codes among preadolescent and adolescent children in remote Aboriginal settlements in Australia, by the genesis of Singlish (Singapore Colloquial English), and by studies of immigrants of various ages who learn the language of their new country. Myers-Scotton $(2002,2006)$ surveys of much of the relevant literature (Myers-Scotton 2000, 2001). These matters are the subject of $\$ 2.2$.

The literatures of variationist sociolinguistics and bilingual acquisition point to the importance of the life stage at which contact-induced change occurs, indicating that changes that occur in young people's speech $(\$ 2.2 .1)$ are likely to be more extensive than changes in adults' speech $(\$ 2.2 .2)$. This points to preadolescence as the life-stage locus of bilingually induced change (\$3.1) but suggests two life-stage loci—childhood and adulthood—for language shift, each with its own consequences, childhood shift being much more common than adult shift (\$3.2). The life-stage loci in their turn allow us to look into the black box and to predict that bilingually induced change may

\footnotetext{
${ }^{7}$ CPs are typically subordinate clauses, and also V2 inversion in Germanic languages. The boundary between the two phases is attributed to Platzack (2001) and reiterated by Rizzi (2005).

${ }^{8}$ Studies of children bilingual in two European languages report much less radical interference, typically involving such phenomena as pragmatically infelicitous use of pronouns in a pro-drop language (Paradis \& Navarro 2003; Serratrice et al. 2004; Hauser-Grüdl et al. 2010). This may be due to the fact that the two European languages are typologically much closer and have more parallel categories than Cantonese and English, but it may also reflect the constrained psycholinguistic testing methods used by researchers. More open-ended studies report more interference, e.g. Bernardini \& Schlyter (2004), Nicoladis (2006).
} 
well entail structural complication, ${ }^{9}$ and language shift the copying of specialist vocabulary $(\$ 4)$.

\subsection{Relating contact events to their outcomes: what we need to know}

To relate the outcomes of contact to the contact events that have caused them, we need generalisations based on cases where we know both the outcomes of contact and, independently attested, the sociolinguistic situations which led to these outcomes. Perhaps surprisingly, the contact literature is rather short of such cases. For example, we lack direct empirical evidence of the conditions under which the languages of the Balkan Sprachbund came to be the way they are.

The Ethiopic Semitic languages are another case in point. They are generally explained as the outcome of language shift after Semitic speakers from south Arabia imposed their language(s) on formerly Cushitic-speaking Ethiopians. Thomason (2001b) says that the link to imperfect learning of Semitic by Cushitic speakers 'is firmly established', but when one examines the sources (Leslau 1945, 1952; Moreno 1948; Little 1974; Hetzron 1975) it becomes clear that this is an inference based on outcomes, not a historically attested fact. The nearest we come to such evidence is a Bayesian phylogenetic analysis based on language data which implies a single Semitic origin for Ethiopic Semitic around 800 BC (Kitchen et al. 2009). On the basis of genetic evidence (Lovell et al. 2005) Kitchen et al. posit language shift and subsequent rapid diversification.

Thurgood $(1999,2001)$ argues that Proto-Chamic, ancestral to the Chamic Austronesian languages of Vietnam and Hainan, was a language closely related to Proto-Malayic that underwent change as the result of shift to it by a large number of Mon-Khmer speakers. He may well be right, but the actual circumstances can only be inferred, and much in Chamic history remains a matter of debate (Blood 1962; Grant 2007; Sidwell 2007, 2008; Brunelle 2009; Thurgood 2010). One set of cases where we can reconstruct the sociolinguistics with reasonable certainty comprises the shift from ancient Negrito languages to Austronesian in the Philippines. I return to this in $\$ 3.2$.

There are several well described cases of shift from a minority language to a majority prestige language: from Hungarian to German at Oberwart (Gal 1979), from Indian languages to English in South Africa (Mesthrie 1992), from Irish to English (Filppula 1986, 1999; Harris 1991; Hickey 1997, 2010;

9 Dahl (2004:286) reaches a similar conclusion with regard to syntactic change and to changes which add complication to a language. 
Pietsch 2008), from Taiwanese Southern Min to Mandarin (Kubler 1985). These mostly provide excellent social history but sometimes fall short in their descriptions of linguistic outcomes.

The pickings are somewhat better with regard to the sociolinguistic circumstances of bilingual copying. We have Haase (1992) on Gascon influence on the Mixe dialect of Basque and Breu (1998, 2003a, 2003b) on Molise Slav, a Croatian dialect spoken by Hercegovinan immigrants to the Campobasso Province of southern Italy since around 1500. Quite a lot is also known about the sociolinguistics of the Turkicisation of Cappadocian Greek (Janse 2009a, 2009b), the outcomes of which are described by Dawkins (1916).

What all these accounts lack, however, is observation of how contactinduced change has taken place. What was the life-stage locus of change? Did it occur in the speech of infants, as generatively based accounts like Lightfoot's $(1979,1989,1991,1999,2006)$ indicate? Did it occur among preadolescents or adolescents (Aitchison 1981:180, 2000:739)? Or adults (Thomason 2011)?

Studies of recent and current language contact events in remote Australian Aboriginal communities are particularly valuable as they describe the role of young people in language change as the change is actually happening (\$2.2.1).

\subsection{Life stages and language change}

\subsubsection{Much language change occurs in young people's speech}

One of very few variationist studies of smallscale dialect contact is James Stanford's work on Sui, a Kadai language of Guizhou Province in SE China. Each Sui village has its own clanlect, which is spoken by men and unmarried women. Marriage normally involves partners from different villages, and the wife relocates to her husband's village. As a result, husband and wife often speak different clanlects. Stanford (2008b) investigated whether the wives accommodated to the clanlect of their new village, and found that they don't: they retain their native clanlect. The Sui place strong value on the clanlect and on its retention, and women who accommodate to their husband's clanlect are objects of ridicule. This contradicts the standard claim that speakers always accommodate to the dialect spoken around them. But the interesting thing is what happens to Sui children. Young children inevitably acquire features of Mum's clanlect, but this gives way quite quickly to Dad's lect-the lect of the village_-as Mum's clanlect invites ridicule. Children as young as three already speak Dad's lect, but with interferences from Mum's lect, and even adolescents of 15-16 may still produce Mum's version of a lexical item (Stanford 2008a, 2008b:469-471). But by adulthood their speech only very rarely betrays their mother's clanlect. 
Stanford's study is a fascinating pointer to the fact that the way an adult talks is laid down in the preadolescent and early adolescent years. It may well, as Aitchison insists, be different from the way the speaker's parents talk.

Recent studies of the rise of mixed languages in two remote Australian Aboriginal communities confirm this. Light Warlpiri (O'Shannessy 2005, 2008, 2009, 2012) and Gurindji Creole (McConvell \& Meakins 2005; Meakins 2008, 2011) have each arisen in a community where just one Aboriginal language is spoken, alongside English-based Aboriginal Kriol. In both Light Warlpiri and Gurindji Creole verbs and verbal morphology are drawn largely from Kriol, noun and case-marking morphology largely from the Aboriginal language. Although the languages appear to have arisen through caregivers' insertional codeswitching within a Kriol matrix, both are now fairly stable. Light Warlpiri has a paradigm of preverbal morphemes which encode realis vs irrealis and person and number of subject. These are clearly calqued on the Warlpiri morphemes which have the same functions. Both are bolded in (2).

2) a. Warlpiri

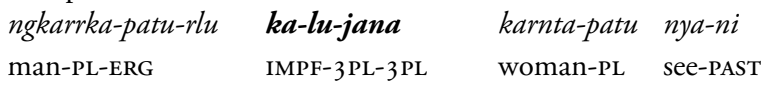

'The men see the women.' (O'Shannessy 2005:27)

b. Light Warlpiri

$\begin{array}{lllll}\text { nyarrpara-wana } \quad \boldsymbol{y u}-\boldsymbol{m} & \text { bai-im } & \text { ngula } & \text { Nungarrayi } \\ \text { where-along } & \text { you-NON.Fut } & \text { buy-TR } & \text { that } & \text { name } \\ \text { 'Where did you buy that, Nungarrayi? '(O'Shannessy } & 2005: 268)\end{array}$

The preverbal paradigm represented by $y u-m$ in (2b) is shown in (3) together with a note of its probable diachronic origins.

3) a. Light Warlpiri paradigm of preverbal morphemes (O’Shannessy 2005:39)

$\begin{array}{lllllll} & 1 \mathrm{sg} & 2 \mathrm{sg} & 3 \mathrm{sg} & 1 \mathrm{pl} & 2 \mathrm{pl} & 3 \mathrm{pl} \\ \text { Realis } & a-m & y u-m & i-m & \text { wi-m } & - & \text { de-m } \\ \text { Irrealis } & a-r r a & y u-r r a & i-r r a & \text { wi-rra } & \text { yumob-rra } & \text { de-rra } \\ \text { Volition } & a-n a & y u-n a & i-n a & \text { wi-na } & - & \text { de-na }\end{array}$

b. Origins: Kriol/English pronouns +

i. $-m$ 'realis' $<$ ? Kriol bin $<$ Eng been

ii.-rra 'irrealis' < Kriol garra < English got to

iii.-na 'volition' < Kriol wana < English wanna (O'Shannessy 2005: 44). 
It isn't quite clear whether the full paradigm had already developed in some variety of Kriol or whether it owes its paradigmaticity entirely to the emergence of Light Warlpiri, but it has obviously undergone significant innovation and systematisation on the path from English to Light Warpiri.

The crucial point here is that both these languages were innovated by young people and are right now mostly spoken only by people under the age of $35-40$, who are passing the language on to their children. Patrick McConvell's historical account of the rise of Gurindji Creole, based on his fieldwork over several decades, makes this very clear. He writes (McConvell 2008:240):

Failure of perfect or near-perfect transmission of the language of previous generations does not solely result from interaction between young children in the early acquisition phase and the parental generation. The young children are also subject to linguistic input from older children, and this peer influence can eclipse that of the parental and grandparental generation. Children and teenagers may deliberately choose not to emulate parents or the old language. Instead they select or build a language variety of their own from among the models available. If there is no counter-weight from the old language, then this peer-group talk can form the basis of the language of the rising generation.

These accounts from Aboriginal Australia illustrate the critical role of preadolescents and adolescents in language change. ${ }^{10}$ But this role is not restricted to Australia. In a variationist study Clarke (2009) describes what happened at the settlement of Sheshatshiu in Labrador, where speakers of different varieties of Innu-aimun (part of the Algonquian Cree continuum) were brought together in 1959. By the time the data for the study were collected a generation later in the early 1980s, a focussed dialect was already emerging, with the teenagers and some speakers in their early 20 s speaking a variety in which the features of the most prestigious group took precedence.

The reader may protest that Light Warlpiri and Gurindji Creole are instances of language intertwining and Sheshatshiu an instance of kioneisation, processes which I claimed above do not occur in smallscale neolithic communities $(\$ 1.3)$. This is true: these cases are not exact analogues of change in neolithic communities. What is at stake here is not the processes themselves but the fact that change is driven by young people.

To justify the claim that contact-induced change in general occurs among the young, one needs to show that the contact effects recorded in the literature do occur in the languages of bilingual children. One of the goals of Yip \& Matthews' (2007:50-53, 227-254) book The bilingual child is to show

${ }_{10}$ These are not the only accounts. One could add Young People's Dyirbal (Schmidt 1985), Dhuwaya (Amery 1985, 1993) and Tiwi (Lee 1987). 
precisely this. In a more recent paper (Matthews \& Yip 2009) they describe the Cantonese-influenced features of their bilingual children's English and ask what would have eventuated if there had been a whole community of such children who had not attended English-language schools from the age of 5. Their answer: something like Singlish—Singapore Colloquial English—which is thought to have come into being as an inter-ethnic lingua franca among students in English-medium schools early in the 20th century and is now arguably a language in its own right (Gupta 1994:32-47, 1998).

A common form of bilingually induced change seen in François' data in (1) is lexical calquing or loan translation, copying the polysemies of the model language into the recipient language. Yip \& Matthews report cases of calquing in the English of their children. Carol Myers-Scotton $(2002,2006)$ cites a number of instances of calquing by bilingual children of immigrants, always with the heritage language as the recipient language. An English-Hungarian bilingual child in the USA uses the Hungarian verb 'to know something' in place of the verb 'to know a person', copying the polysemy of English know. The same child replaces Hungarian kel-t- 'to wake up (TR)' with kel- 'to wake up (INTR)', copying the polysemy of English wake (Bolonyai 1999). Turkish children in Norway have Norwegian-based calques in their Turkish (Türker 2000:72). Russian boys in the USA have English-based calques in their Russian (Schmitt 2000, 2001). ${ }^{11}$

These children also engage in grammatical calques, a form of bilingual copying. The Hungarian children sometimes produce Hungarian SVO clauses instead of SOV or OSV, and in doing so omit the accusative suffix from the direct object on the model of the unmarked English object (Bolonyai 2002, cited by Myers-Scotton 2006:177). At ages 9-11 the Russian boys, who had moved to the US around the age of five with fully developed Russian, employ English-based argument structures with Russian verbs.

A more extreme form of copying is metatypy - syntactic restructuringwhereby, for example, many Austronesian languages of New Guinea have switched from a VO to an OV constituent order in imitation of a Papuan language. Clynes (1992:20) reports that the children of German immigrants in Australia imitate English clause structure by replacing German verb-second with S(Aux)VX.... ${ }^{12}$

11 I have not had access to the dissertations cited in this paragraph and have relied on citations by Myers-Scotton (2002:204, 2006:27) for Bolonyai, Myers-Scotton (2006:199) for Türker and Myers-Scotton (2006:199, 276) for Schmitt.

${ }^{12}$ SAuxX...V and V/XAuxS...V become SAuxVX..., whilst XVS... becomes SVX. Original SVX remains. 


\subsubsection{Much language change doesn't occur in adults' speech}

In line with Aitchison's claim that significant language change occurs among the young, I have so far focussed on instances of contact-induced change among young people. But to support Aitchison's claim fully, one must show that similar language change doesn't usually occur among adults. Studies suggest that Aitchison is perhaps $80 \%$ right. Paul Kerswill's work on dialect contact in English and Norwegian suggests that some types of change are only adopted by children (his cut-off is around age 12): adults don't adopt them. The list in (4) shows the things that adults do and don't acquire when they encounter a new dialect (Kerswill 1996).

4) a. Things adults acquire throughout the lifespan:

i. new vocabulary;

ii. new pronunciations of known words (e.g. $\int$ - $>$ sk- in schedule and /o:/ $>/ D /$ in progress in Montreal English [Boberg 2004]);

iii. a new phonetic realisation of a given phoneme. perhaps only for some speakers and perhaps not always consistently (e.g. $[r]>[R]$ in Montreal French [Sankoff \& Blondeau 2008] or Queen Elizabeth II's vowels [Harrington, Palethorpe \& Watson 2000]).

b. Things adults usually don't acquire:

i. intonation;

ii. new phonological oppositions;

iii. phonological distinctions among lexical items that are not made in their own dialect (like certain lexically diffused changes in English [Kerswill 1996; Payne 1976, 1980]);

iv. new grammatical patterns.

The inability to acquire a new grammatical pattern is exemplified by Meyerhoff \& Walker (2007), who found that speakers from Bequia in the Windward Islands, having spent lengthy periods working in a Canadian or British city, came home sounding far more like speakers of standard English than their stay-at-home peers but retained the variable be-deletion pattern that they had acquired as children.

The work of Blom, Polišenská and Weerman $(2006,2008)$ on the acquisition of Dutch adjective and verb agreement inflection provides a nice contrast between child second-language learners who acquire the inflectional system accurately and adult learners, who don't. They hypothesise that children learn inflections as part of syntactic patterns, whereas adult learning is lexically oriented and does not accommodate inflectional patterns (cf 4)b-iv vs. 4)a-i). They note (2008:333) that adult second-language learner patterns are close to 
those of Afrikaans, which was born out of Dutch in contact with other languages.

Kerswill's conclusion from the list in (4) is similar to Aitchison's, but more moderate:

Paradoxically, adolescents are acquiring a vastly superior knowledge of (though not adherence to) adult norms, including a leap in the size of their vocabulary and a developing awareness of adult style shifting at the stage in their lives when they are most susceptible to peer-based norms. Adolescents are clearly significant bearers of change; their networks allow them to have wider contacts than young children, and their desire for a distinct social identity means that they are willing to modify their speech. At the same time, during this period (at age 16 at the very latest) they no longer have the ability to acquire lexically complex rules, new oppositions, or new intonational systems. Many changes are now word-based... (Kerswill 1996:198)

Kerswill's position is thus that changes occur in children's language between the ages of 6 and 12, i.e. in the preadolescent period, but are propagated furthest in their early teens. Researchers are sometimes a little vague about ages, but Stanford's and Yip \& Matthews' work implies that, at least for some children, change away from caregivers' norms begins earlier than 6 .

Perhaps the most telling evidence for young people as the locus of language change and against adults is found in situations where children and adults are uprooted from one speech community and land up in another.

Much of Kerswill's research in the 1990s concerned the new town of Milton Keynes in southeast England (Kerswill \& Williams 2000, 2005), where families from various parts of England were brought together and a new dialect emerged among young people. One theme which frequently emerges is that preadolescent children acquired the new dialect which was emerging among their peer group, whilst their parents scarcely adapted at all. For example, kids at Milton Keynes all acquired southern English (ou) fronting (Kerswill 1996:192-194), regardless of their caregivers' pronunciation. What is more, both preadolescent and early adolescent speakers acquired the southeast British English rule whereby (ou) is backed before an /1/ immediately preceding a morpheme boundary (rolling, goalie, bowler) but not before /1/ elsewhere (Roland, polo, cola).$^{13}$ None of the parents from dialect areas that lack the rule

\footnotetext{
13 The rule does not apply in British Received Pronunciation, nor in northern or Scottish dialects.
} 
acquired it (Kerswill 1996:195-196). In the light of (4)b-iii), i.e. adults don't apply new phonological distinctions, this is not surprising. Kerswill explains the adults' non-acquisition of (ou) fronting by adding a qualification to (4)a-iii): adults are able to apply new phonetic realisations of old phonemes, but are only likely to do so if the new realisation is sociolinguistically salient (Kerswill 1996:188).

Among immigrants to a new country there is a significant difference between the linguistic adaptation of preadolescents and early adolescents on the one hand and late adolescents and adults on the other. Young people pick up the grammar of their new language well and the old language suffers attrition, whilst adults often have some difficulty acquiring the new language but readily retain their old one (Johnson \& Newport 1989). Myers-Scotton (2006) provides a number of migrant examples beyond those mentioned above, and also makes the point that the critical ages for phonological and grammatical learning evidently differ as immigrants who learn a new language on arrival in their new country only achieve native-like or near native-like pronunciation up to an arrival age of about seven (Myers-Scotton 2006:342). So to Kerswill's list in (4) of things adults (and indeed some adolescents) usually don't acquire we can add the detailed articulatory gestures which make up a speaker's 'accent'.

I have left one matter unaddressed here. Linguists in the Chomskyan generative tradition have worried about the adequacy of the (typically adult) input that infants receive when they acquire their first language(s). The hypothesis that much language change occurs in preadolescence rather than in infancy doesn't get around the question of input, but Stanford's Sui study and Gupta's reconstruction of the emergence of Singlish do imply a more nuanced approach to it. Life-stages form a continuum, and Sui children apparently learn their patrilect not only from their fathers, but perhaps mainly mediated by children and young people whose ages range from just a little older through to young adults. It is in this group, according to dialect contact studies, that variation becomes focussed afresh for each new age cohort. And if it is true that Singlish became focussed on the school playground, then adult input from teachers perhaps had little impact on the details of the focussed variety.

How does all this relate to the question, 'Do bilingually induced and shift-induced change have different outcomes?' Each life-stage locus of contact-induced change has certain kinds of outcome, and these give us diagnostics that we can sometimes use in the reconstruction of contact events. 


\section{The life-stage loci of contact-induced change}

\subsection{The life-stage locus of bilingually induced change}

As François' example in (1) and his interpretation of it imply, bilingually induced change entails rendering one's heritage language increasingly isomorphic with one's second (or further) language in lexical-conceptual and grammatical structure. Because the languages François is dealing with are genealogically related, this is perhaps not immediately obvious, but it is clear enough in Melanesian instances like Takia and Maisin (Figure 1; Ross 1996) where the two languages are unrelated and quite radical changes have taken place in the structures of the heritage language. Where these are changes in grammatical structure, I claim that they were not made by adults: their lifestage locus was in preadolescence.

I have argued elsewhere that the process of bilingual copying has at least three stages. I used to refer to the entire process as 'metatypy' (Ross 1996, 2001, 2003a), but more recently I have deconstructed metatypy, suggesting that widespread lexical calquing and then grammatical calquing apparently always precede the restructuring of the grammar, i.e. metatypy proper (Ross 2006, 2007), giving the event sequence in (5).

5) Prototypical sequence of events in bilingual copying:
a. lexical calquing (loan translation)
b. grammatical calquing
c. syntactic restructuring = metatypy

Lexical calquing has been much discussed in the literature since Weinreich (1953). It is also obvious from listening to, say, conversations in German between German immigrants in Australia, that lexical calquing is something that adults also do.

Grammatical calquing apparently occurs by two routes. The first mimics a construction in the model language by translating its morphemes more or less one-for-one into the recipient language. It begins as lexical calquing that includes copying the valency of a model-language item onto its perceived correspondent in the recipient language. Haase's (1992) account of contactinduced change in Mixe Basque and Breu's (1998, 2003a, 2003b) of the Molise Croatian dialect of southern Italy provide plenty of examples. The socalled complex prepositional construction of Gascon has been calqued as an innovatory complex postpositional construction in Mixe Basque, as the examples in (6) show (Haase 1992:79-80). 
6)

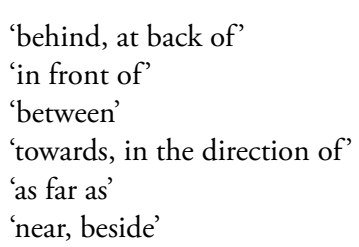

Gascon
au darrèr de $\mathrm{N}$
au davant de $\mathrm{N}$
entermiei de $\mathrm{N}$
$[$ de] cap a $\mathrm{N}$
dinc a $\mathrm{N}$
acostat a $\mathrm{N}$

Mixe Basque
N-GEN gibel-ean
N-GEN aintzin-ean
N-GEN arte-an
N-DAT/ALL bu[r] $]$ z
N-[ALL] artio
N-DAT hurbil

In the top three items of (6) Gascon $a u$ [au] 'at the' becomes the Basque inessive case suffix -ean [-ean] and Gascon de [de] 'of' becomes the Basque genitive case suffix, whilst in the bottom three items Gascon $a$ 'to' becomes the Basque dative or allative case suffix. This is morpheme-for-morpheme translation which renders the categories of the recipient language near-identical to those of the model language, but it employs the morphosyntactic resources of Basque. Arguably this originated in a set of lexical calques, but there is perhaps a new paradigm of complex postpositions in the making.

Grammatical calquing by the second route is not a consequence of lexical calquing. Prince (1998) shows how an existing construction in the recipient language may be used to encode a new function, copying the polyfunctionality of a matching construction in the model language. To distinguish it from lexically based grammatical calquing I label it 'constructional calquing'. Prince's examples of constructional calquing are from Slavic languages into Eastern Yiddish. A simpler example is the Molise Croatian adjectival abstract nominalisation construction in (7)a) where the polyfunctionality of the Italian adjective has been copied into Molise Croatian (Breu 2003). The construction occurs in no other Slavic language and imitates the local Italian dialect construction in (7)a). ${ }^{14}$

7) a. Molise Croatian

ono lipo
DEM:DIST:NEUT beautiful
'beauty', lit. 'that beautiful'
Molise Italian
lo bruttu
DEF:NEUT ugly
'ugliness', lit. 'the ugly'

${ }_{14}$ This construction also has a more complex paradigmatic dimension. Molise Croatian nouns have lost neuter gender and are now either masculine or feminine, on the Italian model. 
The morpheme ono was once the neuter distal demonstrative, but it serves here as the correspondent of the local Italian neuter definite article.

A more complicated instance of constructional calquing is the innovation in Mixe Basque of a passive construction, created by modifying an existing resultative construction to match the Gascon passive (Haase 1992:101-102, 132-133). ${ }^{15}$ The resultative marks a state as relevant at a discourse-related point of time. It is formed with the sequence participle-article + auxiliary (Haase 1992:96), as in (8).

8) Leiho-a (beti) zerra-ti-a dik. window-ART (always) shut-PTCP-ART PRS:ABS:3SG:ERG:3SG 'He (always) has the windows closed.' (Haase 1992:99)

The innovatory passive is formed by adding the participle of the verb 'be' before the intransitive auxiliary, as in (9).

9) Aita salba-tü-a izan-a da.

Father save-PTCP-ART be.PTCP-ART PRS:ABS:3SG

'Father has been saved.' (Haase 1992:102)

The agent, if any, is expressed by a noun phrase in the partitive case, as in (10)a). As Haase (1992:101) points out, this is a calque, an attempt at translation. It is compared below with a Gascon passive clause, and, as the subscripts on corresponding constituents show, there has been no adoption of Romance constituent order.

10) a. A[b]antxü $\boldsymbol{x a k u ̈ r}_{1}$ bat $_{2}$-eta-[r]ik $\boldsymbol{k}_{3}$ ausiki $_{4}$ izan $_{5} \quad$ tzün $_{6}$. almost dog one-TRN ${ }^{16}$-PART bite.PTCP be.PTCP PRET:ABS:3SG 'He was almost bitten by a dog.' (Haase 1992:132)

b. Se $_{6} \quad$ estado $_{5}$ swañado $_{4} \quad$ per $_{3}$ de $_{2} \quad$ syrs. be.1s be.PTCP care.for.PTCP by ART.INDF.PL sisters 'I was cared for by sisters' (Kelly 1973:204)

The question which these examples raise is, Might adults have innovated Molise adjectival abstract nominalisation or the Basque passive? Extrapolating

Neuter gender thus occurs only in adjectives, demonstratives and sto 'what? ' and only in a few constructions of which this is one (Rešetar 1997:125-126).

15 This is an abbreviated version of the discussion in Ross (2007:126-127).

16 'transnumeral'. 
from Kerswill's findings, the answer is 'no': adults innovate on a onelexical-item-at-a-time basis, but they do not innovate new constructional patterns. These are new patterns which probably arose on the lips of preadolescent speakers, an inference supported by the increase in complexity that the Mixe passive entails (see $\$ 4$ ).

The third step in (5), syntactic restructuring, goes beyond grammatical calquing. Even the innovation of a Basque passive uses Basque morphosyntactic resources and Basque syntax. Syntactic restructuring, on the other hand, also entails copying syntax from the model language. Syntactic restructuring is considerably less common than the stages that precede it. One reason for this may be that where the languages in contact have radically different grammatical systems, syntactic restructuring is obstructed. But how different must the systems be for there to be obstruction? And under what sociolinguistic conditions might obstruction be overcome? These are questions about which the contact literature at present says little. At any rate, clear examples of syntactic restructuring in languages whose sociolinguistic history we have independent knowledge of are hard to find, and I will resort here to an example from the Oceanic language Takia. At least its reconstructed history rests on quite a firm footing.

In Proto Oceanic, the language from which Takia is descended, the expression 'in front of the house' is reconstructable with the construction in (11)a), but the Takia construction in (11)a) is almost its mirror image because it entails a copy of the Waskia construction in (11)b), or perhaps of an isomorphic construction in one of Waskia's (Trans-New Guinea) relatives (Ross 1996:188-190, 2003b: 224-229).

\begin{tabular}{|c|c|}
\hline a. & $\begin{array}{l}\text { Proto Oceanic } \\
*_{i} \text { nako-ña Rumaq } \\
\text { at face-POss: } 3 \text { sg house } \\
\text { 'at the face of the house' }\end{array}$ \\
\hline b. & $\begin{array}{l}\text { Takia } \\
a b \text { nao-n na } \\
\text { house face-POss:3sG at } \\
\text { 'at the face of the house' }\end{array}$ \\
\hline c. & $\begin{array}{l}\text { Waskia } \\
\text { kawam koma se } \\
\text { house face.POss:3sg at } \\
\text { 'at the face of the house' }\end{array}$ \\
\hline
\end{tabular}

The most striking cases of syntactic restructuring are of the kind found in Takia and other Oceanic SOV languages of New Guinea. Every bit of 
evidence says that Proto Oceanic, from which they are all descended, was a VO language, and that a more recent descendant was SVO. I don't think anyone denies that the SOV languages are the outcome of contact (Lynch 1981:10-111), as Oceanic SOV languages only occur in the neighbourhood of Papuan SOV languages. The puzzle is: How did the constituent order change in these languages take place?

Heine (2008) suggests that a new order is usually one that was already present in the recipient language, perhaps as a marked option or with a different function. In general I agree with him, but OV (and OSV) clauses only occur in Oceanic SVO languages when the object is a marked topic, and SOV clauses do not occur at all. The only way I can explain the SVO-to-SOV change is as an innovation by young Takia-Waskia bilinguals who displayed a level of inventiveness similar to that of the Australian Aboriginal young people or the English-Hungarian bilingual children mentioned in $\$ 2.2 .1$ (see also Dahl 2004:286).

I proposed the three-stage sequence of bilingual copyings shown in (5) because case studies provide us with instances of each step in the sequence. For example, a perusal of Munshi's (2010) analysis of contact in Srinagar Burushaski shows this to be a language where the effect of bilingualism is extensive lexical calquing but not much else, so it represents Stage (a). Haase's examples from Mixe Basque show that the language has undergone lexical and grammatical calquing, i.e. Stage (b). But Takia has undergone syntactic restructuring as well and represents Stage (c). The three-stage sequence is implicational because we do not find instances where, for example, syntactic restructuring has occurred without lexical calquing.

To summarise, whilst adults are involved in the first stage of bilingual copying, namely lexical calquing, the evidence strongly indicates that grammatical calquing and restructuring are innovations made during preadolescence and propagated in adolescence.

Johanson (2008:77) suggests that grammatical calquing and restructuring are simply points on a cline, a suggestion based on the fact that both are 'combinational copying' in his framework. But the two phenomena are usually distinct. Grammatical calquing copies structural components but not their ordering, whereas syntactic restructuring also copies their syntax. In an example like (12)), from Prince Edward Island French, what has occurred is syntactic copying of English preposition stranding, i.e. a change in the sequence of elements.

12) Quoi ce-que tu as parlé hier à Jean de?

What it-that you have talked yesterday to John of

'What did you speak yesterday to John about?' (King 2000:146) 
Like the Takia construction in (11)a) and the change from SVO to SOV, (12) is an instance of restructuring, whereas quite complex cases of grammatical calquing like the Mixe passive do not involve syntactic copying.

Disciples of Frans van Coetsem will protest that I have not specified whether bilingual copying happens through borrowing or through imposition, in other words whether the psycholinguistically dominant language of the bilingual speakers doing the copying is the language into which they are copying or from which they are copying. If I read him correctly, Winford (2005:413) believes that that grammatical calquing and restructuring must be impositions. I agree: they are impositions by children who are growing up bilingually, copying from their psychologically dominant language into their other language, as Winford (2005:408) hints in his discussion of the imposition of Turkish morphosyntactic patterns by Turkish-dominant children on Cappodocian Greek. ${ }^{17}$ Van Coetsem himself (1995:70, 2000:52) would perhaps have explained bilingual copying as adult imposition, based on his belief that a speaker's dominant language can change in adulthood, but the evidence offered in $\$ 2.2$ speaks against adult involvement.

The proposal that bilingual copying entails imposition by children has a further implication to which I will return in $\$ 4$, but first I will look at what happens during language shift.

\subsection{The life-stage loci of language shift}

Bilingually induced change has only one major life-stage locus, namely preadolescence and early adolescence, but language shift has two.

When we talk about shift-induced change we are usually referring to the effects of incomplete second-language learning, but instances of this, it seems to me, are rare in smallscale societies. The norm is that children grow up bi- or multilingual (often inheriting previous generations' bilingual copies). Shift then consists in the abandonment of the community's heritage language in favour of another language in their repertoire (Weinreich 1953:94). The one area of the target language in which speakers may have less than native competence is specialist vocabulary, especially where there are cultural differences between heritage-language speakers of the two languages. Thurston (1989) describes the shift of speakers of the Papuan language Anêm to the Oceanic language Lusi, both on New Britain, a large island to the east of New Guinea

${ }^{17} \mathrm{He}$ also sees a role for Greek-dominant speakers. I infer that these would be adults whose Turkish-based lexical calques would contribute to their Turkish-dominant children's copying into Greek (I owe this insight to Bethwyn Evans). 
(Figure 1). Because Anêm speakers are people of the montane forest and Lusi speakers' are oriented economically to the sea, Thurston claims that the shifting speakers took a substantial amount of lexicon relating to objects and activities of the montane forest with them when they abandoned Anêm in favour of Lusi. A comparison of the vocabulary of Lusi with that of its closer Oceanic relatives and with the reconstructed lexicon of Proto Oceanic shows that, although he has overstated his case a little, he is right: the shifting speakers did retain an amount of vocabulary from their heritage language (Ross 2013) and this is the only evidence in Lusi of language shift. ${ }^{18}$

There is one well studied set of Austronesian cases where we have strong circumstantial evidence for this kind of shift. These are the languages of the Negritos of the Philippines. It is certain beyond reasonable doubt on genetic evidence (Delfin et al. 2011) that Negritos are descended from very early arrivals in Southeast Asia who predate by many millennia the settlement of Austronesian speakers in the Philippines around 2200 BC (Bellwood 1985:74, 113). At the time Austronesian speakers arrived, the Negritos were still huntergatherers, and some groups remained so until the 20th century. Thanks to Lawrence Reid's (1987, 1989, 1991, 1994a, 1994b, 2007) detailed work, we know that the 15 or so languages of the Negritos are almost all ${ }^{19}$ closely related to the Austronesian languages of their immediate neighbours. Since they cannot have spoken an Austronesian language before the arrival of Austronesian speakers, we must infer that language shift occurred. The obvious hypothesis is that Negritos long ago saw the advantages of entering into a symbiotic relationship with their agricultural neighbours and, after a period of bilingualism, eventually lost their earlier languages apart from the varying quantities of specialised vocabulary which they retained in their new languages. ${ }^{20}$ Were it not for these lexical transfers, we would have no evidence of language shift (cf $\$ 1.4$ ), since the Negrito languages retain the morphological complexity of the Austronesian languages of the Philippines, presumably because they had already spoken them for generations as they gradually abandoned their heritage languages. ${ }^{21}$

If the cultures of the languages involved in a shift situation like those just described are similar, and often they are, then the amount of vocabulary

\footnotetext{
18 Thurston says there are also structural effects, but there aren't: see $\$ 4$.

19 The exception is Inati, but this is still significantly more closely related to Philippine languages than to other Austronesian languages.

20 This hypothesis is similar to those proposed with regard to Pygmy groups in Central Africa (Verdu et al. 2009; Bahuchet, forthcoming).

${ }^{21}$ Reid (1994a) proposes an alternative hypothesis involving pidginisation, but the presentday languages provide none of the evidence of simplification that this hypothesis would require.
} 
retained from the heritage language may be so small as to leave no record of shift (Brigitte Pakendorf. pers. comm.).

Shift-induced linguistic effects do occur, however, where language shift for some reason doesn't follow two or three generations of bilingualism. Apart from transfer of specialist lexicon three kinds of shift-induced effect recur in the literature.

13) a. phonological transfer

b. constructional calquing

c. simplified (morpho)syntax

The first, phonological transfer, is the result of adults' inability to make new phonological oppositions, as noted in (4)b-4)b.iii). We find it, for example, in Irish English and Indian English. However, it occurs only very rarely in Melanesia. The only instance I know of is Madak, an Oceanic language spoken in New Ireland, another large island to the east of New Guinea (Figure 1), which shares its phoneme inventory and a set of phonological rules with the neighbouring Papuan language, Kuot (Ross 1994a). There were no other obvious indicators of contact, and I interpret this as the result of Kuot-speaking adults shifting to an Oceanic language, and then suddenly becoming isolated from other speakers of the target language. A possible scenario is that the Kuot speakers became refugees in an Oceanic speaking village as the result of interclan hostilities, but then fell out with their Oceanic-speaking hosts before the next generation could learn the language. ${ }^{22}$

The second shift-induced effect listed in (13) is constructional calquing. This again reflects an adult inability, namely that of acquiring new grammatical structures (34)b-4)b.iv). Regional rural Irish English has a number of calqued constructions, each an imitation of an Irish construction. Perhaps the best known is the immediate perfective (Pietsch 2008; Hickey 2010:156), illustrated in (14).

14) a. Irish

Tá siad tar=éis an obair a dhéanamh
is they after the work COMP do
'They have completed the work.' (Hickey 2010:156)
Irish English
They are after doing the work.

22 This scenario predicts that Madak will contain specialist vocabulary copied from Kuot, but the relevant data are not available to check. 
Another consists of the Irish English clefts which serve a wider range of functions than in other English varieties and in which the focussed constituent is one that would not be extracted in other English dialects (Harris 1991:197-199).

15) Irish (focus = non-finite VP):

Is ag déanamb a chuid ceachtannai atá Tadhg. is at doing his portion lessons REL:be Tim Irish English: It's doing his lessons that Tim is. (Harris 1991)

A glance at the different morpheme orderings of Irish and Irish English in (14) and (15) tells us that this is constructional calquing, not grammatical restructuring. Constructional calquing will of course only eventuate as an effect of shift if the two languages coexist bilingually for long enough for the transfer to happen and if the shifting community remains sufficiently distinct from other target language communities for its calques to stay in circulation.

It is often suggested that shift may result in morphosyntactic simplification, and one might cite Afrikaans as an example. However, I have found it impossible to pin down specific cases in Melanesia apart from the local varieties of Pacific Pidgin. Thurston claims that Austronesian Lusi, mentioned above, is the simplified outcome of language shift by speakers of Papuan Anêm (Thurston 1982:61, 1994:583-584). The presence of Anêm specialist vocabulary in Lusi suggests that shift occurred, but a comparison (Goulden 1996) of the phonology and grammar of Lusi with its two closest relatives and neighbours, Bariai and Kove, shows no simplification. Elsewhere, Thurston (1989:558) claims that these three languages have undergone simplification as a result of their use by second-language speakers, but again the comparative evidence does not support the claim (Ross 2013). What Thurston saw was that these three languages are morphologically much more transparent than their Austronesian neighbours on New Britain, but this is a conservative Oceanic feature: it is the neighbours that have become morphologically opaque, not Bariai, Lusi and Kove that have become more transparent. It may of course be that Bariai, Lusi and Kove have through contact been prevented from increasing in complexity (Dahl 2004:295), but this kind of hypothesis is almost impossible to verify.

\section{Implications of the life-stage locus model: complication, simplification and the comparative method}

The simplification issue takes us to a further implication of the life-stage locus model. Children's and adults' informal language learning styles are quite 
different. Children learn any number of phonological and grammatical irregularities. Adults typically don't. In fact adult informal language learning is mainly word-based: adults may continue to add to their vocabulary and they may change the pronunciations of words they already know, but they don't handle new irregularities readily. The reasons why this is so remain somewhat controversial (Hernandez, Mi \& MacWhinney 2005), and I have tried to avoid saying that adults can't do certain things, as this entails neurological or psychological assumptions on which, it seems, the jury is still out. Obviously adults do learn new languages, and sometimes learn them well, but this typically entails a large amount of practice and a strong motivation to acquire the language, perhaps as a means of identification with their new community. ${ }^{23}$

Various linguists have suggested that where a smallscale language is not used for communication with adult outsiders, it tends toward increasing complexity and irregularity. There are two reasons for this. First, the child's learning style is one that accommodates large amounts of irregularity, and without countervailing simplification, the language will tend to become more irregular and more complex (Andersen 1988; Trudgill 2002). 'Complexity' in this context is a relative phenomenon and effectively means 'hard for an adult speaker to learn'. It may consist of unusual sounds, difficult sound combinations, morphophonemic complexities, unpredictable categories like gender, and morphological irregularities (Dahl 2004). Second, in smallscale communities interlocutors are able to rely on shared knowledge and on face-to-face interaction and talk becomes less explicit and less transparent, so that the language acquires highly specific lexical items, suppletion and opaque formulae (Kay 1977:24; Peters 1983:81; Thurston 1994:580; Everett 2005; Wray \& Grace 2007).

In a bilingual situation where speakers are endeavouring to express the categories of their psychologically dominant language in their other language, there is considerable scope for increase in complexity as copied features are added to the recipient language. These may well include what Thomason (2010) classes as hard-to-learn features. Because of the differences in child and adult learning styles, the changes entailed in this complexification are most likely to occur and to become regularised among preadolescent speakers.

\footnotetext{
${ }^{23}$ I am grateful to Martin Haspelmath for pointing out the strength of identification as a learning motive.
} 
Table 1 Takia postverbal enclitics.

\begin{tabular}{|c|c|c|c|c|c|c|c|}
\hline & & $\phi,=i,=y a$ & $\mathrm{R}: \mathrm{I}$ & & & & \\
\hline$\varnothing$ & & $=u,=w a$ & IRR:I & $\varnothing$ & & & \\
\hline$=s e$ & REPET & $=d a$ & IMPF:I & $=k,=a k$ & BOUNDARY & & \\
\hline$=l a$ & TERM & & & & & & \\
\hline$=n a$ & DUR & $\varnothing$ & & $\varnothing$ & & & \\
\hline$=[w] o$ & INTENT & $=d o$ & CONTIN & $=g u$ & SEQ & $=g,=g o$ & $\mathrm{R}: \mathrm{D}$ \\
\hline & & & & $=t a$ & REASON & $\begin{array}{l}=p,=p e \\
=d,=d e,=d i\end{array}$ & $\begin{array}{l}\text { IRR:D } \\
\text { ADD:D }\end{array}$ \\
\hline
\end{tabular}

Takia provides an example of complication. The example in (16) is a typical Takia clause chain.

16) $A g o=p \quad$ parapar $=n a \quad m i-d i r i=\boldsymbol{p} \quad y$-en $=\boldsymbol{d} \boldsymbol{d}=\boldsymbol{p} \quad$ teik PRO=IRR:M platform=POSTP s:1EP-put=IRR:M s:3s- sleep=CONTIN=IRR:M brother

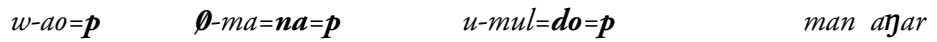
s:2S-go=IRR:M S:2S-stay $=$ DUR=IRR:M S:2S-return $=$ CONTIN $=I R R: M \quad$ TPC canarium $\begin{array}{llc}\text { parapar }=n \boldsymbol{a} & y \text {-en }=\boldsymbol{d o}=\boldsymbol{p} & \boldsymbol{u} \text {-le }=\boldsymbol{w a} . \\ \text { platform=POSTP } & \mathrm{s}: 3 \mathrm{~s} \text {-sleep=CONTIN=IRR:M } & \text { s:2S-see=IRR:F }\end{array}$

'Then we will put them [the canarium nuts] on the smoke bed, and they will stay, and, my brother, you will go and stay [away] for a while, and when you return, you will see canarium nuts here on the platform.'

But Takia is an Oceanic language, and Oceanic languages don't normally form clause chains. They are a feature of neighbouring Papuan languages of the Trans New Guinea family (Ross 1994b, 2002a, 2007). The Takia verb complex retains Oceanic subject coreferencing prefixes like the mi-s:1EP of $m i$ dirip in the first line. But the verb complex has acquired a Papuan-like bundle of enclitics, shown in bold, which mark the clause as realis or irrealis in mood and as medial or final within its chain. Here, $=p$ of $m i$-dirip and other verbs marks them as irrealis (IRR) and medial (M) within the chain, and the = wa at the end marks the verb as irrealis and final $(\mathrm{F})$, in the chain. If the clause is chain-medial, an optional enclitic or enclitic sequence precedes $=p$ and indicates whether its relationship to the following clause is one of sequence, simultaneity or cause. The system as a whole is shown in Table 1.

Other than mood, these are categories that are otherwise marked morphologically only in neighbouring Papuan languages of the Trans New Guinea family, where they are also encoded after the verb stem, as suffixes (Ross 1994b, 2002a). Oceanic languages usually do encode mood, but with preverbal morphemes that Takia has lost. Comparative evidence says that this new 
Table 2 Kaulong pronouns.

\begin{tabular}{|c|c|c|c|c|c|c|}
\hline & IINC & IEXC & 2 & 3 & 3ID & $3 \mathrm{sw}$ \\
\hline \multirow[t]{3}{*}{ SG } & - & yo & yon, som & MASC hiay & - & sun \\
\hline & & & & $F E M$ vut & - & $\ldots$ \\
\hline & & & & NEUT $\boldsymbol{l i}$ & - & $\cdots$ \\
\hline DL & toy & tuk & mom & vuloy & goy & (vulon) \\
\hline PC & suk & piuk & miuk & vuluk & ngiuk & (vuluk) \\
\hline PL & it & pim & vom, po, som & po & bi & sun \\
\hline
\end{tabular}

Table 3 Arop-Lokep pronouns.

\begin{tabular}{lllll}
\hline & $1 \mathrm{INC}$ & $1 \mathrm{EXC}$ & 2 & 3 \\
$\mathrm{SG}$ & - & $a u$ & on & $y a$ \\
$\mathrm{DL}$ & $a-r u$ & $a m-r u$ & $a \eta-r u$ & $y a-r u$ \\
$\mathrm{PL}$ & $i d i$ & $a m$ & $a \eta$ & $d i$ \\
\hline
\end{tabular}

morphosyntactic system has emerged in Takia over a number of generations (Ross 2008). None of the new morphemes appear to be borrowed, and $=p$ and the corresponding realis enclitic $=g$ are descended from earlier conjunctions. The very complexity of this system suggests emergence through bilingual childhood innovation. ${ }^{24}$

Kaulong, a Western Oceanic language of southern New Britain (Figure 1), exemplifies paradigmatic complication. Its free pronoun paradigm, shown in Table 2, is considerably more complex than the typical Western Oceanic paradigm of nearby Arop-Lokep in Table 3. Kaulong distinguishes masculine, femine and neuter genders in the third person singular, and differing third person pronouns in all four numbers according to whether the referent is identical (ID) with or different (switched: sw) from the previous referent (Throop 1992, Ross 2002b). These (in bold) are not Oceanic categories. Kaulong's four numbers (singular, dual, paucal and plural) are not unusual in Oceanic languages, but dual (DL) is less common and paucal (PC) unusual in Western Oceanic and their forms point to innovation rather than inheritance.

These complications again witness to bilingually induced change rather than shift-induced change. There is no longer a Papuan language nearby, but the presence of scattered Papuan languages on New Britain attests to the probability that the island was occupied by many more Papuan speaking groups before their languages were displaced by Oceanic, and the

${ }_{24}$ Ross (2001:147), clutching at an ethnographic straw offered by McSwain (1977), suggested that Takia contact-induced change was due to trade interactions with Waskia speakers. I now think this was wrong. 
complications of Kaulong reflect the erstwhile presence of a Papuan language in which the community was once bilingual—a well grounded reconstructio ex silentio (\$1.4).

The converse of complication is simplification, and the model implies that simplification should happen when adult speakers shift language. As noted above, such cases seem very rare in the smallscale societies of Melanesia, and languages which Thurston thought had become relatively simple and transparent through shift had in fact retained simplicity and transparency. Proto Oceanic is reconstructed as morphologically transparent, and, assuming that the reconstruction is broadly correct, this may reflect its use as a lingua franca. For a period of time it was probably spoken over a large area (Pawley 2008). It is also probably true that the more immediate ancestor of the Oceanic languages that Thurston discusses was also a lingua franca (Ross 2013). There is a view - and it seems a reasonable one - that new learners tend to reduce redundant variability in a language (Schilling-Estes 2002), but its validity is hard to demonstrate. From Melanesia we have only circumstantial evidence that the use of a language by outsiders keeps it simple.

The New Britain cases raise a tangential but important point. Complexity and simplicity are relative concepts. One can only say that a language has increased or decreased in complexity and simplicity, and in order to do this where there are no written records, one must use the comparative method. Thurston's claims are based on the assumption that all language change can be explained by contact, but this is clearly not the case. Application of the comparative method shows that what he took to be simplification brought about by shift is in fact a bundle of inherited features. This is unfortunate, as his case study of the languages of northwest New Britain, presented in a series of publications (Thurston 1982, 1987, 1989, 1992, 1994), has been cited by scholars writing about contact. For example, Winford (2005:413) writes that Thurston's shift scenario 'supports the view that the AN [Oceanic Austronesian] languages were socially dominant on the coast, and were acquired by NAN [Non-Austronesian $=$ Papuan] speakers who imposed their L1 structure on them.' This is indeed Thurston's claim, but the comparative evidence doesn't confirm it (Ross 2013). Instead it says that the the coastal Oceanic languages are rather conservative.

\section{Concluding discussion}

The tabulation in (17) summarises the effects of bilingually induced change and shift-induced change. Here 'early' and 'late' refer to the period over which contact takes place, not to life stages. 
17)

\begin{tabular}{|c|c|c|}
\hline \\
\hline \\
\hline \multicolumn{3}{|c|}{$\begin{array}{lll} & \text { bilingually induced change } & \text { shift-induced change } \\
\text { lexical calquing } & \text { yes, early } & \text { no }\end{array}$} \\
\hline $\begin{array}{l}\text { lexically based grammatical } \\
\text { calquing }\end{array}$ & perhaps & no \\
\hline constructional calquing & perhaps & perhaps \\
\hline syntactic restructuring & late, if at all & no \\
\hline simplicity/complexity & complication & simplification? \\
\hline lexical transfer & perhaps & perhaps specialist \\
\hline phonological transfer & late? & early if at all \\
\hline
\end{tabular}

The top three rows of (17) are discussed in $\$ 3.1$ and $\$ 3.2$, and the fourth row, complication and simplification, in $\$ 4$. A little needs to be said about the two bottom rows.

As an effect of bilingually induced change I have written 'perhaps' against lexical transfer. Aikhenvald's (2003:22, 2007:237) account of the Vaupés situation shows that cultural constraints can prevent it. Speakers of Athapaskan languages are also said to avoid borrowing (Rice 2004). I have suggested elsewhere (Ross 2003a:193) that lexical transfer is not in an implicational relationship with the other effects of bilingual copying. Here I apparently differ from Thomason (2001b, 2010), who thinks that by default lexical borrowing precedes other forms of copying.

I have written 'late?' against phonological transfer as an effect of bilingually induced change. The two New Guinea cases of bilingually induced change that I have studied most carefully, Takia and Maisin (Ross 1996), do not show phonological transfer between the languages in contact. Both have undergone phonological change, but if this change is the outcome of contact, it is an indirect outcome, because the outcomes don't resemble anything in the languages with which they have been in contact. ${ }^{25}$

So does the tabulation in (17) provide us with any clear diagnostics of the distinction between bilingually- and shift-induced change, diagnostics that we can use in trying to reconstruct the histories of languages? The answer is 'yes, some'. They are:

25 Thomason (2001b) has assumed that Takia must have undergone some form of phonological copying that I had not mentioned, but I don't think it has. I do realise that there are cases where phonological transfer has not only occurred but seems to have happened earlier in the sequence of events. This is a matter that needs more research, and particularly careful examination of the circumstances of individual cases. 
18)

a. For bilingually induced change:

i. lexical calquing, especially on a large scale;

ii. lexically based grammatical calquing;

iii. syntactic restructuring;

iv. complication.

Shift:

Adult shift:

i. transfer of specialist vocabulary.

i. phonological copying in the absence of other significant contact effects;

ii. constructional calquing in the absence of lexical calquing;

iii. perhaps simplification.

Statements like these are at best probabilistic. The converses of all these statements except (18)a) are untrue. Bilingually induced change doesn't necessarily or even usually extend to syntactic restructuring (and differences between the grammatical systems of the two languages may obstruct it), and shift is not necessarily accompanied by a transfer of specialist vocabulary or by phonological transfer. But bilingual copying does entail lexical calquing: without it nothing is copied.

The list of diagnostics in (17) is not revolutionary. Apart from the inclusion of the complexity/simplicity criterion, it differs only in small ways from the diagnostics in Thomason (2001b). What I hope I have done is to show why the list of diagnostics is the way it is by grounding it in the life-stage locus hypothesis and to show why complication, and perhaps simplification, can reasonably be added to it.

Finally, the claim I am making about the role of children in bilingually induced change is capable of empirical verification or refutation. If we are to understand how contact-induced change takes place in smallscale societies, then we need careful variationist observations of bi- or multilingual smallscale societies.

\section{References}

Aikhenvald, Alexandra Y., 2003. Language contact in Amazonia. Oxford: Oxford University Press.

Aikhenvald, Alexandra Y., 2003. Mechanisms of change in areal diffusion: new morphology and language contact. Journal of Linguistics 39:1-29.

Aikhenvald, Alexandra Y., 2007. Semantics and pragmatics of grammatical relations in the Vaupés linguistic area. In Alexandra Y. Aikhenvald \& R.M.W. Dixon, eds, Grammars in contact: A cross-linguistic typology, 237-266. Oxford: Oxford University Press. 
Aitchison, Jean, 1981. Language change: progress or decay? London: Fontana.

Aitchison, Jean, 2000. Psycholinguistic perspectives on language change. In Brian D. Joseph \& Richard D. Janda, eds, The Handbook of Historical Linguistics, 736-743. Oxford: Blackwell.

Amery, Rob, 1985. A new diglossia: Comtemporary speech varieties at Yirrkala in North East Arnhem Land. MA thesis, Australian National University.

Amery, Rob, 1993. An Australian koine: Dhuwaya, a variety of Yolyu Matha spoken at Yirrkala in North East Arnhemland. International Journal of the Sociology of Language 99:45-64.

Andersen, Henning, 1988. Centre and periphery: adoption, diffusion and spread. In Jacek Fisiak, ed., 39-85. Berlin: Mouton de Gruyter.

Bahuchet, Serge, forthcoming. The linguistic diversity of the African rainforest "Pygmy" huntergatherers. In Tom Güldemann, Patrick McConvell \& Richard A. Rhodes, eds, The languages of hunter-gatherers: Global and historical perspectives. Cambridge: Cambridge University Press.

Bakker, Peter \& Maarten Mous, eds, 1994. Mixed languages: 15 case studies in language intertwining. Amsterdam: Institute for Functional Research into Language and Language Use (IFOTT). (Studies in Language and Language Use 13)

Baldi, Philip \& B. Richard Page, 2006. Review of Theo Vennemann, Europa Vasconica-Europa Semitica, Mouton de Gruyter, Berlin, 2003. Lingua 116:2183-2220.

Bellwood, Peter S., 1985. Prehistory of the Indo-Malaysian archipelago. Sydney: Academic Press.

Bellwood, Peter S. \& Eusebio Dizon, 2008. Austronesian cultural origins: out of Taiwan, via the Batanes Islands, and onwards to western Polynesia.. In Alicia Sanchez-Mazas, Roger Blench, Malcolm Ross, Ilia Peiros \& Marie Lin, eds, Past human migrations in East Asia: Matching archaeology, linguistics and genetics, 23-39. London: Routledge. (Routledge Studies in the Early History of Asia 5)

Blom, Elma, Daniela Polišenská \& Fred Weerman, 2006. Effects of age on the acquisition of agreement inflection. Morphology 16:313-336.

Blom, Elma, Daniela Polišenská \& Fred Weerman, 2008. Articles, adjectives and age of onset: The acquisition of Dutch grammatical gender. Second Language Research 24:297-331.

Blood, Doris Walker, 1962. Reflexes of Proto-Malayo-Polynesian in Cham. Anthropological Linguistics 4.9:11-20.

Boberg, Charles, 2004. Real and apparent time in language change: Late adoption of changes in Montreal English. American speech 79:250-269.

Bolonyai, Agnes, 1999. The hidden dimensions of language contact. PhD dissertation, University of South Carolina.

Bolonyai, Agnes, 2002. Case systems in contact: Syntactic and lexical case in bilingual child language. Southwest Journal of Linguistics 21:1-34.

Breu, Walter, 1998. Romanisches Adstrat im Moliseslavischen. Die Welt der Slaven 43:339-354.

Breu, Walter, 2003a. Impersonales Neutrum im Moliseslavischen. In S. Kempgen, U. Schweier \& T. Berger, eds, Rusistika - Slavistika - Lingvistika. Festschrift für Werner Lehfeldt zum 60. Geburtstag, 57-71. München: Otto Sagner. (Die Welt der Slaven, Sammelbände Bd. 19)

Breu, Walter, 2003b. Bilingualism and linguistic interference in the Slavic-Romance contact area of Molise (Southern Italy). In R. Eckardt, K. von Heusinger \& Ch. Schwarze, eds, Words in time: diachronic semantics from different points of view, 351-373. Berlin: Mouton de Gruyter.

Brunelle, Marc, 2009. Diglossia and monosyllabization in Eastern Cham: A sociolinguistic study. In James N. Stanford \& Dennis R. Preston, eds, Variation in indigenous minority languages, 47-75. Amsterdam: John Benjamins. 
Clarke, Sandra, 2009. Sociolinguistic stratification and new dialect formation in a Canadian aboriginal community: Not so different after all? In James N. Stanford \& Dennis R. Preston, eds, Variation in indigenous minority languages, 109-128. Amsterdam: John Benjamins.

Clyne, Michael, 1992. Linguistic and sociolinguistic aspects of language contact, maintenance and loss: Towards a multifacet theory. In Willem Fase, Koen Jaspaert \& Sjaak Kroon, eds, Maintenance and loss of minority languages, 17-36. Amsterdam: John Benjamins.

Coetsem, Frans van, 1995. Outlining a model of the transmission phenomenon in language contact. Leuvense Bijdragen 84:63-85.

Coetsem, Frans van, 2000. A general and unified theory of the transmission process in language contact. Heidelberg: Winter.

Dahl, Östen, 2004. The growth and maintenance of linguistic complexity. Amsterdam: John Benjamins.

Dawkins, R.M., 1916. Modern Greek in Asia Minor: A study of the dialects of Silli, Cappadocia, and Phárasa. Cambridge: Cambridge University Press.

Delfin, Frederick et al., 2011. The Y-chromosome landscape of the Philippines: extensive heterogeneity and varying genetic affinities of Negrito and non-Negrito groups. European Journal of Human Genetics 19:224-23.

Enfield, Nicholas J., 2003. Linguistic epidemiology: Semantics and grammar of language contact in mainland Southeast Asia. London: Routledge Curzon.

Eska, J.F., 1994. Rethinking the evolution of Celtic constituent configuration. Münchener Studien zur Sprachwissenschaft 55:7-39.

Everett, Daniel L., 2005. Cultural constraints on grammar and cognition in Pirahã: Another look at the design features of human language. Current Anthropology 46:621-646.

Filppula, Markku, 1986. Some aspects of Hiberno-English in a Functional Sentence Perspective. Joensuu: University of Joensuu. (University of Joensuu Publications in the Humanities 7)

Filppula, Markku, 1999. The grammar of Irish English: Language in Hibernian style. London: Routledge.

Foley, William A., 1986. The Papuan languages of New Guinea. Cambridge: Cambridge University Press.

François, Alexandre, 2011. Social ecology and language history in the northern Vanuatu linkage: A tale of divergence and convergence. Journal of Historical Linguistics 1:175-246.

Garrett, Andrew, 2006. Convergence in the formation of Indo-European subgroups: Phylogeny and chronology. In Peter Forster \& Colin Renfrew, eds, Phylogenetic methods and the prehistory of languages, 139-151. Cambridge: McDonald Institute for Archaeological Research.

Gensler, Orin David, 1993. A typological evaluation of Celtic/Hamito-Semitic syntactic parallels. PhD dissertation, University of California at Berkeley.

Goulden, Rick J., 1996. The Maleu and Bariai languages of West New Britain. In Malcolm Ross, ed., Studies in languages of New Britain and New Ireland, 1: Austronesian languages of the North New Guinea Cluster in northwestern New Britain, 63-144. Canberra: Pacific Linguistics. (Pacific Linguistics C-135)

Grant, Anthony P., 2007. Admixture and after: The Chamic languages and the creole prototype. In Umberto Ansaldo, Stephen Matthews \& Lisa Lim, eds, Deconstructing creole, 109-139. Amsterdam: John Benjamins.

Gupta, Anthea Fraser, 1994. The step-tongue: Children's English in Singapore. Clevedon: Multilingual Matters.

Gupta, Anthea Fraser, 1998. Singapore Colloquial English or deviant Standard English? In Jan Tent \& France Mugler, eds, SICOL: proceedings of the Second International Conference on 
Oceanic Linguistics, 1: Language contact, 43-57. Canberra: Australian National University. (Pacific Linguistics C-141)

Haase, Martin, 1992. Sprachkontakt und Sprachwandel im Baskenland: Einflusse des Gaskognischen und Franzosischen auf das Baskische. Hamburg: Buske.

Harrington, Jonathan, Sallyanne Palethorpe \& Catherine I. Watson, 2000. Does the Queen speak the Queen's English? Nature 408:927.

Harris, John, 1991. Conservatism versus substratal transfer in Irish English. In Peter Trudgill \& J.K. Chambers, eds, Dialects of English: Studies in grammatical variation. London: Longman.

Hauser-Grüdl, Nicole, Lastenia Arencibia Guerra, Franziska Witzmann, Estelle Leray \& Natascha Müller, 2010. Cross-linguistic influence in bilingual children: Can input frequency account for it? Lingua 120:2638-2650.

Heine, Bernd, 2008. Contact-induced word order change without word order change. In Peter Siemund \& Noemi Kintana, eds, Language contact and contact languages, 33-60. Amsterdam: John Benjamins. (Hamburg Studies on Multilingualism 7)

Hernandez, Arturo, Ping Li \& Brian MacWhinney, 2005. The emergence of competing modules in bilingualism. Trends in Cognitive Sciences 9:220-225.

Hetzron, Robert, 1975. Genetic classification and Ethiopian Semitic. In James Bynon \& Theodora Bynon, eds, Hamito-Semitica, 103-127. The Hague: Mouton.

Hewitt, Steve, 2007. Remarks on the Insular Celtic/Hamito-Semitic question. In Raymond Karl \& David Stifter, eds, The Celtic world: Critical concepts in historical studies, 230-268. London: Routledge.

Hickey, Raymond, 2007. Syntax and prosody in language contact and shift. In Hildegard L.C. Tristram, ed., The Celtic Languages in Contact: Papers from the workshop within the framework of the XIII International Congress of Celtic Studies, Bonn, 26-27 July 2007, 235-245. Potsdam: Potsdam University Press.

Hickey, Raymond, 2010a. Contact and language shift. In Raymond Hickey, ed., The handbook of language contact, 151-169. Oxford: Wiley-Blackwell.

Hickey, Raymond, ed., 2010b. The handbook of language contact. Oxford: Wiley-Blackwell.

Hulk, Aafke \& Natascha Müller, 2000. Bilingual first language acquisition at the interface between syntax and pragmatics. Bilingualism: Language and Cognition 3:227-244.

Hung, Hsiao-chun, 2005. Neolithic interaction between Taiwan and northern Luzon: the pottery and jade evidences from the Cagayan Valley. Journal of Austronesian Studies 1:109-134.

Isaac, Graham R., 2007. Celtic and Afro-Asiatic. In Hildegard L.C. Tristram, ed., The Celtic Languages in Contact: Papers from the workshop within the framework of the XIII International Congress of Celtic Studies, Bonn, 26-27 July 2007, 25-80. Potsdam: Potsdam University Press.

Janse, Mark, 2009a. Greek-Turkish language contact in Asia Minor. Etudes Helleniques-Hellenic Studies 17:37-54.

Janse, Mark, 2009b. Agglutination, Watkins' Law, and the psychology of double inflections in Asia Minor Greek. In Mark Janse, Brian D. Joseph \& Angeliki Ralli, eds, Studies in Modern Greek dialects and linguistic theory. Nicosia: Research Centre of the Holy Monastery of Kykkos.

Johanson, Lars, 2002. Contact-induced change in a code-copying framework. In Mari C. Jones \& Edith Esch, eds, Language change: the interplay of internal, external and extralinguistic factors, 285-313. Berlin: Mouton de Gruyter.

Johanson, Lars, 2008. Remodeling grammar: Copying, conventionalization, grammaticalization. In Peter Siemund \& Noemi Kintana, eds, Language contact and contact languages, 61-79. Amsterdam: John Benjamins. (Hamburg Studies on Multilingualism 7) 
Johnson, Jacqueline S. \& Elissa L. Newport, 1989. Critical period effects in second language learning: The influence of maturational state on the acquisition of English as a second language. Cognitive Psychology 21:60-99.

Kay, Paul, 1977. Language evolution and speech style. In B.G. Blount \& M. Sanches, eds, Sociocultural dimensions of language change, 21-33. New York: Academic Press.

Kelly, Reine Cardaillac, 1973. A descriptive analysis of Gascon. The Hague: Mouton.

Kerswill, Paul, 1994a. Babel in Buckinghamshire? Pre-school children acquiring accent features in the New Town of Milton Keynes. In G. Melchers \& N.-L. Jonannesson, eds, Nonstandard varieties of language, 64-83. Stockholm: Almqvist \& Wiksell. (Acta Universitatis Stockholmiensis)

Kerswill, Paul, 1994b. Dialects converging: Rural speech in urban Norway. Oxford: Oxford University Press.

Kerswill, Paul, 1996. Children, adolescents, and language change. Language Variation and Change 8:177-202.

Kerswill, Paul \& Ann WiIliams, 1992. Some principles of dialect contact: Evidence from the New Town of Milton Keynes. In I. Philippaki-Warburton \& R. Ingham, eds, Working Papers 1992, 68-90. Reading: Department of Linguistic Science, University of Reading.

Kerswill, Paul \& Ann Williams, 2000. Creating a new town koine: Children and language change in Milton Keynes. Language in Society 29:65-115.

Kerswill, Paul \& Ann Williams, 2005. New towns and koineization: linguistic and social correlates. Linguistics 43:1023-1048.

King, Ruth, 2000. The lexical basis of grammatical borrowing: a Prince Edward Island French case study. Amsterdam: John Benjamins.

Kitchen, Andrew, Christopher Ehret, Shiferaw Assefa \& Connie J. Mulligan, 2009. Bayesian phylogenetic analysis of Semitic languages identifies an Early Bronze Age origin of Semitic in the Near East. Proceedings of the Royal Society B, Biological Sciences 276:2703-2710.

Kubler, Cornelius C., 1985. The development of Mandarin in Taiwan: a case study of language contact. Taipei: Student Book Co..

Labov, William, 1966. The social stratification of English in New York City. Washington DC: Center for Applied Linguistics.

Labov, William, 1970. Stages in the acquisition of Standard English. In H. Hungerford, J. Robinson \& J. Sledd, eds, English linguistics, 275-301. Glenview IL: Scott Foresman.

Labov, William, 1972a. Language in the inner city. Philadelphia: University of Pennsylvania Press.

Labov, William, 1972b. Sociolinguistic patterns. Philadelphia: University of Pennsylvania Press.

Lass, Roger, 1997. Historical linguistics and language change. Cambridge: Cambridge UP.

Lee, Jennifer, 1987. Tiwi today: A study of language change in a contact situation. Canberra: Pacific Linguistics. (Pacific Linguistics C-96)

Leslau, Wolf, 1945. The influence of Cushitic on the Semitic languages of Ethiopia: a problem of substratum. Word 1:59-82.

Leslau, Wolf, 1952. The influence of Sidamo on the Ethiopic languages of Gurage. Language 28:63-81.

Lightfoot, David, 1979. Principles of diachronic syntax. Cambridge: Cambridge University Press.

Lightfoot, David, 1989. The child's trigger experience: Degree-O learnability. Behavioral and Brain Sciences 12:321-334.

Lightfoot, David, 1991. How to set parameters: Arguments from language change. Cambridge, MA: MIT Press.

Lightfoot, David, 1999. The development of language: Acquisition, change and evolution. Oxford: Blackwell.

Lightfoot, David, 2006. How new languages emerge. Cambridge: Cambridge University Press. 
Little, Greta DuBose, 1974. Approaches to Amharic historical syntax. PhD dissertation, University of North Carolina at Chapel Hill.

Lovell, A., C. Moreau, V. Yotova, F. Xiao, S. Bourgeois, D. Gehl, J. Bertranpetit, E. Schurr and D. Labuda, 2005. Ethiopia: between Sub-Saharan Africa and Western Eurasia. Annals of Human Genetics 69:275-287.

Lupyan, Gary \& Rick Dale, 2010. Language structure is partly determined by social structure. PLOS ONE 5:1-10 and additional online materials.

Lynch, John, 1981. Melanesian diversity and Polynesian homogeneity: the other side of the coin. Oceanic Linguistics 20:95-129.

McConvell, Patrick, 2008. Language mixing and language shift in indigenous Australia. In J.H. Simpson \& G. Wigglesworth, eds, Children's language and multilingualism: indigenous language use at home and school, 237-260. London: Continuum.

McConvell, Patrick \& Felicity Meakins, 2005. Gurindji Kriol: A mixed language emerges from code-switching. Australian Journal of Linguistics 25:9-30.

McSwain, Romola, 1977. The past and future people. Melbourne: Oxford University Press.

Matthews, Stephen \& Virginia Yip, 2009. Contact-induced grammaticalization: Evidence from bilingual acquisition. Studies in Language 33:366-395.

Meakins, Felicity, 2008. Unravelling languages: Multilingualism and language contact in Kalkaringi. In J.H. Simpson \& G. Wigglesworth, eds, Children's language and multilingualism: indigenous language use at home and school, 283-302. London: Continuum.

Meakins, Felicity, 2011. Case-marking in contact: The development and function of case morphology in Gurindji Kriol. Amsterdam: John Benjamins.

Mesthrie, Rajend, 1992. English in language shift: The history, structure and sociolinguistics of South African Indian English. Cambridge: Cambridge University Press.

Meyerhoff, Miriam \& James A. Walker, 2007. The persistence of variation in individual grammars: Copula absence in 'urban sojourners' and their stay-at-home peers, Bequia (St Vincent and the Grenadines). Journal of SocioLinguistics 11:346-366.

Moreno, Martino Mario, 1948. Lazione del cuscito sul sistema morfologico delle lingue semitiche dell'Ethiopia. Rassegna di Studi Etiopici 7:121-130.

Müller, Natascha \& Aafke Hulk, 2001. Crosslinguistic influence in bilingual language acquisition: Italian and French as recipient languages. Bilingualism: Language and Cognition 4:1-2.

Munshi, Sadaf, 2010. Contact-induced language change in a trilingual context: The case of Burushaski in Srinagar. Diachronica 27:32-72.

Myers-Scotton, Carol, 2000. Four types of morpheme: Evidence from Aphasia, codeswitching and second language acquisition. Linguistics 38:1053-1100.

Myers-Scotton, Carol, 2001. Explaining aspects of codeswitching and their implications. In Janet Nicol, ed., One mind, two languages: Bilingual language processing, 84-114. Oxford: Blackwell.

Myers-Scotton, Carol, 2002. Contact linguistics: Bilingual encounters and grammatical outcomes. Oxford: Oxford University Press.

Myers-Scotton, Carol, 2006. Multiple voices: An Introduction to bilingualism. Malden MA: Blackwell.

Nichols, Johanna, 1998. The Eurasian spread zone and the Indo-European dispersal. In Roger M. Blench \& Matthew Spriggs, eds, Archaeology and language, 2: Correlating archaeological and linguistic hypotheses, 220-266. London: Routledge.

Nicoladis, Elena, 2006. Cross-linguistic transfer in adjective-noun strings by preschool bilingual children. Bilingualism: Language and Cognition 9:15-32.

O’Shannessy, Carmel, 2005. Light Warlpiri: A new language. Australian Journal of Linguistics 25:31-57. 
O'Shannessy, Carmel, 2008. Children's production of their heritage language and a new mixed language. In J.H. Simpson \& G. Wigglesworth, eds, Children's language and multilingualism: indigenous language use at home and school, 261-282. London: Continuum.

O'Shannessy, Carmel, 2009. Language variation and change in a North Australian indigenous community. In James N. Stanford \& Dennis R. Preston, eds, Variation in indigenous minority languages, 419-439. Amsterdam: John Benjamins.

O'Shannessy, Carmel, 2012. The role of code-witched input to children in the origin of a new mixed language. Linguistics 50:305 - 340 .

Paradis, Johanne \& Samuel Navarro, 2003. Subject realization and crosslinguistic interference in the bilingual acquisition of Spanish and English: what is the role of the input? Journal of Child Language 30:371-393.

Pawley, Andrew, 2006. Papuan languages. In Keith Brown, ed., Elsevier Encyclopaedia of Languages and Linguistics. 2nd edition. Oxford: Elsevier.

Pawley, Andrew, 2008. Where and when was Proto Oceanic spoken? Linguistic and archaeological evidence. In Yury A. Lander \& Alexander K. Ogoblin, eds, Language and text in the Austronesian world: Studies in honour of Ülo Sirk, Lincom Europa. Munich: Lincom Europa. (Studies in Austronesian Linguistics 06)

Payne, Arvilla, 1976. The acquisition of the phonological system of a second dialect. PhD dissertation, University of Pennsylvania.

Payne, Arvilla, 1980. Factors controlling the acquisition of the Philadelphia dialect by out-ofstate chidren. In William Labov, ed., Locating language in time and space, 143-177. NewYork: Academic Press.

Peters, A.M., 1983. Units of language acquisition. Cambridge: Cambridge University Press.

Pietsch, Lukas, 2008. Prepositional aspect constructions in Hiberno-English. In Peter Siemund \& Noemi Kintana, eds, Language contact and contact languages, 213-236. Amsterdam: John Benjamins. (Hamburg Studies on Multilingualism 7)

Platzack, Christer, 2001. The vulnerable C-domain. Brain and Language 77:364-377.

Polomé, Edgar C., 1986. The non-Indo-European component of the Germanic lexicon. In A. Etter, ed., . Berlin: Moutin de Gruyter.

Polomé, Edgar C., 1990. The Indo-Europeanization of northern Europe: The linguistic evidence. Journal of Indo-European Studies 18:331-338.

Polomé, Edgar C., 1997. How Indo-European is Germanic? In Irmengard Rauch \& Gerald F. Carr, eds, Insights in Germanic Linguistics II, 197-206. Berlin: Moutin de Gruyter.

Prince, Ellen F., 1998. The borrowing of meaning as a cause of internal syntactic change. In Monika S. Schmid, Jennifer R. Austin \& Dieter Stein, eds, Historical linguistics 1997: Selected papers from the 13th International Conference on Historical Linguistics, Düsseldorf, 10-17 August 1997, 339-362. Amsterdam: John Benjamins.

Reid, Lawrence A., 1987. The Early Switch hypothesis: Linguistic evidence for contact between Negritos and Austronesians. Man and Culture in Oceania 3:41-59.

Reid, Lawrence A., 1989. Arta, another Philippine Negrito language. Oceanic Linguistics 28:47-74.

Reid, Lawrence A., 1991. The Alta languages of the Philippines. In Ray Harlow, ed., VICAL 2: Western Austronesian and contact languages. Papers from the Fifth International Conference on Austronesian Linguistics., 265-297. Auckland: Linguistic Society of New Zealand.

Reid, Lawrence A., 1994a. Possible non-Austronesian lexical elements in Philippine Negrito languages. Oceanic Linguistics 33:37-72.

Reid, Lawrence A., 1994b. Unravelling the linguistic histories of Philippine negritos. In Tom Dutton \& Darrell Tryon, eds, Language contact and change in the Austronesian world, 443-475. Berlin: Mouton de Gruyter. 
Reid, Lawrence A., 2007. Historical linguistics and Philippine hunter-gatherers. In Loren Billings \& Nelleke Goudswaard, eds, Piakandatu ami Dr. Howard P. McKaughan, 6-32. Manila: Linguistic Society of the Philippines and SIL Philippines.

Rešetar, Milan, 1997 [1911]. Le colonie serbocroate nell'Italia Meridionale. Campobasso: Amministrazione Provinciale Campobasso.

Rice, Keren, 2004. Language contact, phonemic inventories, and the Athapaskan language family. Linguistic Typology 8:321-383.

Rizzi, Luigi, 2005. On the grammatical basis of language development: A case study. In Guglielmo Cinque \& Richard S. Kayne, eds, The Oxford handbook of comparative syntax, 70-109. Oxford: Oxford University Press.

Ross, Malcolm, 1994a. Areal phonological features in north central New Ireland. In Tom Dutton \& Darrell Tryon, eds, Language contact and change in the Austronesian world, 551572. Berlin: Mouton de Gruyter.

Ross, Malcolm, 1994b. Describing inter-clausal relations in Takia. In Ger P. Reesink, ed., Topics in descriptive Austronesian linguistics, 40-85. Leiden: Vakgroep Talen en Culturen van Zuidoost-Azie en Oceanie, Rijksuniversiteit te Leiden. (Semaian 11)

Ross, Malcolm, 1996. Contact-induced change and the comparative method: cases from Papua New Guinea. In Mark Durie \& Malcolm Ross, eds, The comparative method reviewed: regularity and irregularity in language change, 180-217. New York: Oxford University Press.

Ross, Malcolm, 2001. Contact-induced change in Oceanic languages in north-west Melanesia. In R.M.W. Dixon \& Alexandra Y. Aikhenvald, eds, Areal diffusion and genetic inheritance: problems in comparative linguistics, 134-166. Oxford: Oxford University Press.

Ross, Malcolm, 2002a. Takia. In John Lynch, Malcolm Ross \& Terry Crowley, eds, The Oceanic languages, 216-248. Richmond: Curzon Press.

Ross, Malcolm, 2002b. Kaulong. In John Lynch, Malcolm Ross \& Terry Crowley, eds, The Oceanic languages, 387-409. Richmond: Curzon Press.

Ross, Malcolm, 2003a. Diagnosing prehistoric language contact. In Raymond Hickey, ed., Motives for language change, 174-198. Cambridge: Cambridge University Press.

Ross, Malcolm, 2003b. Talking about space: terms of location and direction. In Malcolm Ross, Andrew Pawley \& Meredith Osmond, eds, The lexicon of Proto Oceanic: The culture and environment of ancestral Oceanic society, 2: The physical world, 221-284. Canberra: Pacific Linguistics.

Ross, Malcolm, 2005. Pronouns as a preliminary diagnostic for grouping Papuan languages. In Andrew Pawley, Robert Attenborough, Jack Golson \& Robin Hide, eds, Papuan pasts: cultural, linguistic and biological histories of Papuan-speaking peoples, 15-66. Canberra: Pacific Linguistics. (Pacific Linguistics 572)

Ross, Malcolm, 2007. Calquing and metatypy. Journal of Language Contact: Thema 1:116-143.

Ross, Malcolm, 2008. A history of metatypy in the Bel languages. Journal of Language Contact: Thema :149-164.

Ross, Malcolm, 2013. Reconstructing the history of languages in northwest New Britain: inheritance and contact. Journal of Historical Linguistics $3 / 2$.

Ross, Malcolm, Andrew Pawley \& Meredith Osmond, eds, 1998. The lexicon of Proto Oceanic: The culture and environment of ancestral Oceanic society, 1: Material culture. Canberra: Pacific Linguistics. (Pacific Linguistics C-152).

Ross, Malcolm, Andrew Pawley \& Meredith Osmond, eds, 2008. The lexicon of Proto Oceanic: The culture and environment of ancestral Oceanic society, 3: Plants. Canberra: Pacific Linguistics. (Pacific Linguistics 599)

Ross, Malcolm, Andrew Pawley \& Meredith Osmond, eds, 2011. The lexicon of Proto Oceanic: The culture and environment of ancestral Oceanic society, 4: Animals. Canberra: Pacific Linguistics. (Pacific Linguistics 621) 
Sankoff, Gillian \& Hélène Blondeau, 2008. Language change across the lifespan:/r/ in Montreal French. Language 83:560-588.

Schilling-Estes, Natalie, 2002. On the nature of isolated and post-isolated dialects: Innovation, variation and differentiation. Journal of Sociolinguistics 6:64-85.

Schmidt, Annette, 1985. Young people's Dyirbal. Cambridge: Cambridge University Press.

Schmitt, Elena, 2001. Beneath the surface: Signs of language attrition in immigrant children from Russia. PhD dissertation, University of South Carolina.

Schmitt, Elena, 2000. Overt and covert codeswitching in immigrant children from Russia. International Journal of Bilingualism 4:9-28.

Serratrice, L., A. Sorace \& S. Paoli, 2004. Crosslinguistic influence at the syntax-pragmatics interface: Subjects and objects in English-Italian bilingual and monolingual acquisition. Bilingualism: Language and Cognition 7:183-205.

Sidwell, Paul, 2007. The Mon-Khmer substrate in Chamic: Chamic, Bahnaric and Katuic contact. In Ratree Wayland, John Hartmann \& Paul Sidwell, eds, SEALS XII: papers from the 12th meeting of the Southeast Asian Linguistics Society (2002), 113-128. Canberra: Pacific Linguistics.

Sidwell, Paul, 2008. Issues in the morphological reconstruction of Proto-Mon-Khmer. In Claire Bowern, Bethwyn Evans \& Luisa Miceli, eds, Morphology and language history: In honour of Harold Koch, 257-271. Amsterdam: John Benjamins.

Stanford, James N., 2008a. Child dialect acquisition: New perspectives on parent/peer influence. Journal of Sociolinguistics 12:567-596.

Stanford, James N., 2008b. A sociotonetic analysis of Sui dialect contact. Language Variation and Change 20:409-450.

Stanford, James N., 2009. Clan as a sociolinguistic variable: Three approaches to Sui clans. In James N. Stanford \& Dennis R. Preston, eds, Variation in indigenous minority languages, 463-484. Amsterdam: John Benjamins.

Stanford, James N. \& Dennis R. Preston, 2009. The lure of a distant horizon: Variation in indigenous minority languages. In James N. Stanford \& Dennis R. Preston, eds, Variation in indigenous minority languages, 1-20. Amsterdam: John Benjamins.

Thomason, Sarah Grey, 2001a. Language contact: An introduction. Edinburgh: Edinburgh University Press.

Thomason, Sarah Grey, 2001b. Contact-induced typological change. In Martin Haspelmath, Ekkehard Koenig, Wulf Oesterreicher \& Wolfgang Raible, eds, Language typology and language universals/Sprachtypologie und sprachliche Universalien: An international handbook, 1640-1648. Berlin: Walter de Gruyter.

Thomason, Sarah Grey, 2010. Contact explanations in linguistics. In Raymond Hickey, ed., The handbook of language contact, 31-47. Oxford: Wiley-Blackwell.

Thomason, Sarah Grey, 2011. Is morphosyntactic change really rare? Bilingualism: Language and Cognition 14:146-148.

Throop, Craig, 1992. Kaulong grammar essentials. Unpublished manuscript, Summer Institute of Linguistics, Ukarumpa.

Thurgood, Graham, 1999. From ancient Cham to modern dialects: Two thousand years of language contact and change. Honolulu: University of Hawai'i Press. (Oceanic Linguistics Special Publication 28)

Thurgood, Graham, 2001. Learnability and direction of convergence in Cham: The effects of long-term contact on linguistic structures. In Proceedings of the Eleventh Annual Western Conference on Linguistics, 507-527. Fresno: California State University.

Thurgood, Graham, 2010. Hainan Cham, Anong, and Eastern Cham: Three languages, three social contexts, three patterns of change. Journal of Language Contact-Varia 3:39-65. 
Thurston, William R., 1982. A comparative study of Anêm and Lusi. Canberra: Pacific Linguistics. (Pacific Linguistics B-83)

Thurston, William R., 1987. Processes of change in the languages of north-western New Britain. Canberra: Pacific Linguistics. (Pacific Linguistics B-99)

Thurston, William R., 1989. How exoteric languages build a lexicon: esoterogeny in West New Britain. In Ray Harlow \& Robin Hooper, eds, VICAL 1, Oceanic languages: papers from the Fifth International Conference on Austronesian Linguistics, 555-579. Auckland: Linguistic Society of New Zealand.

Thurston, William R., 1992. Sociolinguistic typology and other factors effecting change in northwestern New Britain, Papua New Guinea. In Tom Dutton, ed., Culture change, language change: Case studies from Melanesia, 123-139. Canberra: Pacific Linguistics. (Pacific Linguistics C-120)

Thurston, William R., 1994. Renovation and innovation in the languages of north-western New Britain. In Tom Dutton \& Darrell Tryon, eds, Language contact and change in the Austronesian world, 573-609. Berlin: Mouton de Gruyter.

Trudgill, Peter, 1983. Language contact and language change: On the rise of the creoloid. In Peter Trudgill, ed., On dialect: Social and geographical perspectives, 102-107. New York: New York University Press.

Trudgill, Peter, 1989. Contact and isolation in linguistic change. In Leiv Egil Breivik \& Ernst Håkon Jahr, eds, Language change: contributions to the study of its courses, 227-237. Berlin: Mouton de Gruyter. Trudgill, Peter, 2000. Sociolinguistics: An introduction to language and society. 4th edition. London: Penguin.

Trudgill, Peter, 2001. Contact and simplification: Historical baggage and directionality in linguistic change. Linguistic Typology 5:371-374.

Trudgill, Peter, 2002. Linguistic and social typology. In Jack K. Chambers, Peter Trudgill \& N. Schilling-Estes, eds, Handbook of language variation and change, 707-728. Oxford: Blackwell.

Trudgill, Peter, 2009. Sociolinguistic typology and complexification. In Geoffrey Sampson, David Gil \& Peter Trudgill, eds, Language complexity as an evolving variable, 98-109. Oxford: Oxford University Press.

Türker, Emel, 2000. Turkish-Norwegian codeswitching: Evidence for intermediate and secong generation Turkish immigrants in Norway. PhD dissertation, University of Oslo.

Vennemann, Theo, 1994. Linguistic reconstruction in the context of European prehistory. Transactions of the Philological Society 92:215-284.

Vennemann, Theo, 2003a. Languages in prehistoric Europe north of the Alps. In Alfred Bammesberger \& Theo Vennemann, eds, Languages in prehistoric Europe, 319-332. Heidelberg: Winter.

Vennemann, Theo, 2003b. Syntax und Sprachkontakt: Mit besondere Berücksichtigung der indogermanischen Sprachen des Nordwestens. In Alfred Bammesberger \& Theo Vennemann, eds, Languages in prehistoric Europe, 333-364. Heidelberg: Winter.

Vennemann, Theo, 2003c. Vorindogermanische Substrate. In Theo Vennemann, ed., Europa Vasconica - Europa Semitica, 517-590. Berlin: Mouton de Gruyter.

Verdu, Paul, Frederic Austerlitz, Arnaud Estoup, Renaud Vitalis, Myriam Georges, Sylvain Théry, Alain Froment, Sylvie Le Bomin, Antoine Gessain, Jean-Marie Hombert, Lolke Van der Veen, Lluis Quintana-Murci, Serge Bahuchet \& Evelyne Heyer, 2009. Origins and genetic diversity of pygmy hunter-gatherers from western Central Africa. Current Biology 19:312-318.

Weinreich, Uriel, 1953. Languages in contact: Findings and problems. New York: Linguistic Circle of New York. (Publications of the Linguistic Circle of New York 1) 
Winford, Donald, 2005. Contact-induced changes: classification and processes. Diachronica 22:373-427.

Wray, Alison \& George W. Grace, 2007. The consequences of talking to strangers: Evolutionary corollaries of socio-cultural influences on linguistic form. Lingua 117:543-578.

Yip, Virginia \& Stephen Matthews, 2007. The bilingual child: Early development and language contact. Cambridge: Cambridge University Press. 